\title{
Mobility and fractionation of rare earth elements in argillaceous sediments: Implications for dating diagenesis and low-grade metamorphism
}

\author{
Matthias OHR, * Alexander N. Halliday, and Donald R. PEacor \\ Department of Geological Sciences, The University of Michigan, Ann Arbor, MI 48109, USA
}

(Received October 22, 1992; accepted in revised form June 10, 1993)

\begin{abstract}
We report $\mathrm{Sm}-\mathrm{Nd}$ and $\mathrm{Rb}-\mathrm{Sr}$ data for the fine fractions of Lower Paleozoic argillaceous rocks from Wales, UK, and New York, USA, spanning the range of low-grade metamorphic conditions from the diagenetic zone (zeolite facies) to the epizone (greenschist facies). In all cases, leaching of the fine fractions results in a high ${ }^{147} \mathrm{Sm} /{ }^{144} \mathrm{Nd}(0.09-0.29)$ acid-soluble component and a complementary low ${ }^{147} \mathrm{Sm} /{ }^{144} \mathrm{Nd}(0.05-0.14)$ residual component. The observed fractionation is an ancient feature related to diagenesis, burial, and metamorphism. The magnitude of $\mathrm{Sm}-\mathrm{Nd}$ fractionation between leachates and residues, as well as the resulting $\mathrm{Sm}-\mathrm{Nd}$ ages, vary as a function of grain size and metamorphic grade. Uncleaved Welsh mudrocks of the diagenetic zone yield Sm-Nd leachate-residue ages of $453-484 \mathrm{Ma}$, in agreement with their Llanvirnian to Caradocian biostratigraphic ages, whereas higher grade rocks of the anchizone and epizone yield Sm-Nd ages as young as $413 \mathrm{Ma}$. These ages are transitional between the time of deposition and the time of regional deformation related to the Acadian Orogeny at $390 \mathrm{Ma}$. Distinct convex-upward rare earth element (REE) patterns of the leachates suggest that the precipitation of early diagenetic apatite controls the trace element budget of the rock, forcing a depletion of middle REEs on the subsequently formed diagenetic phyllosilicates. The amount of organic matter present and the extent of later prograde reactions are probable modifiers of this fractionation process. Ordovician and Devonian clastic rocks associated with the Trenton and Onondaga limestones of New York yield single-sample and multi-sample $\mathrm{Sm}-\mathrm{Nd}$ isochron ages that agree well with their biostratigraphic ages of $454 \mathrm{Ma}$ and $390 \mathrm{Ma}$, respectively. The REE fractionation observed in shale leachates of the Ordovician Utica Formation is related to $\mathrm{Ca} / \mathrm{Mg}$ of the bulk rock, and hence to the composition of the diagenetic carbonate cement. In all cases the $\mathrm{Sm}$-Nd system remained closed subsequent to the peak of diagenesis or metamorphism, including the North American rocks that show no evidence of being isotopically reset during widespread remagnetization of the subjacent limestone units in the late Paleozoic.
\end{abstract}

\section{INTRODUCTION}

MINERAL ASSEMBLAGES THAT form during diagenesis and low-grade metamorphism provide a record of important events related to deposition, burial, and deformation. Associated chemical transfer processes through time range from mobility of rare earth elements (REEs) in the porewater column below the sediment-water interface (e.g., ELDERFIELD and SHOLKOVITZ, 1987) to the sequence of phyllosilicate reconstitution during burial (e.g., KISCH, 1983), and eventually to recrystallization of major and accessory phases related to the development of a tectonic fabric during regional deformation and metamorphism. Many of these processes are controlled by the presence of crustal fluids, their physical and chemical properties, and the degree and magnitude of fluid-rock interaction (HALLIDAY et al., 1991). The reconstruction of pertinent low-temperature processes through time with sufficient resolution establishes a temporal framework in which to place the sequence of diagenetic and metamorphic modifications that lead toward thermodynamically stable assemblages.

The most frequently used isotopic methods for dating sedimentary assemblages utilize the $\mathrm{Rb}-\mathrm{Sr}$ and the $\mathrm{K}-\mathrm{Ar}$ decay systems. The most commonly encountered problems include

* Present address: Dames \& Moore, 2325 Maryland Road, Willow Grove, PA 19090, USA. disequilibrium between individual phases, uncertainty about the initial isotopic compositions, and thermal isotopic resetting. In this study, the potential of single-sample Sm-Nd dating of mineral assemblages corresponding to diagenesis and incipient metamorphism is evaluated. This approach involves a simple leaching technique applied to fine-grained fractions of argillaceous sediments, with the effect of chemically separating soluble phases from the insoluble phyllosilicates. We interpret the resulting mixing-lines as the equivalents of twopoint isochrons because we can independently demonstrate that the REEs in leachate and residue are derived from cogenetic phases, and that the $\mathrm{Sm}-\mathrm{Nd}$ system has remained closed since the events of interest. The advantage of such a single-sample isochron approach is that the initial isotopic composition of $\mathrm{Nd}$ can be constrained for each sample, thereby eliminating the deleterious isotopic effects of variable provenance.

\section{Sm-Nd Systematics of Argillaceous Sediments}

The range of Sm-Nd ratios in argillaceous sediments is primarily determined by their provenance, although average grain size and content of organic material are important factors as well. High Sm-Nd ratios result from high abundances of mafic components and are typical for coarse-grained lithologies. The extent to which $\mathrm{Sm}-\mathrm{Nd}$ ratios are controlled by variable organic carbon content is poorly understood. STILLE and ClAUER (1986) reported increasing Sm-Nd ratios with 
greater organic carbon content in chlorite-rich shales of the Gunflint Formation, whereas BRos et al. (1992) observed a negative correlation between organic content and $\mathrm{Sm}-\mathrm{Nd}$ ratios in Proterozoic volcaniclastic shales.

In addition to variations in $\mathrm{Sm}-\mathrm{Nd}$ ratio among different lithologies, it has been shown that acid leaching of bulk sediments and their various grain size fractions results in two sample complements with distinct $\mathrm{Sm}-\mathrm{Nd}$ ratios: the leachates typically display high $\mathrm{Sm}-\mathrm{Nd}$ ratios and the corresponding residues display low Sm-Nd ratios (GROMET et al., 1984; AWWILLER and MACK, 1991; OHR et al., 1991; Bros et al., 1992). This sizable fractionation between leachable and residual sample components was observed to be accompanied by apparent neodymium isotopic equilibrium in the fine fractions $(<0.1 \mu \mathrm{m})$ of Eocene and Paleocene Gulf Coast shales (OHR et al., 1991). Since isotopic equilibrium was approached with decreasing grain size, and hence increasing proportion of authigenic phases, we proposed that REE fractionation occurred during clay diagenesis and involved both phyllosilicates and accessory phases such as apatite and sphene. From this we predicted that single sample Sm-Nd dating of diagenesis and low-grade metamorphism may be possible, provided the events were of sufficient age. In this study the results of experiments designed to test this hypothesis are presented, using shales and slates of Ordovician to Devonian age. The $\mathrm{Sm}-\mathrm{Nd}$ ages derived from leachate-residue pairs of the fine fractions of undeformed shales are shown to correspond to the time of early diagenesis, and hence may serve as an efficient means of establishing the depositional or stratigraphic age of the sediment. In contrast, low-grade pelites from the anchizone and epizone have developed a cleavage related to regional metamorphism and deformation, and reveal ages transitional between those of deposition and metamorphism.

Leaching experiments have been conducted to address the overall chemical and isotopic effects resulting from the acid attack on fine-grained phyllosilicates (e.g., CHAUDHURI and BROOKINS, 1979; KRALIK, 1984; ClaUER et al., 1993). Whereas the mineral content, texture, and composition of bulk separates and leached residues of phyllosilicates can be studied in depth by a variety of methods, chemical analysis is the only means of assessing the origin and significance of leachates. Lacking other constraints, the chemical and isotopic composition of leachates have therefore generally been inferred to be representative or remnant of a diagenetic fluid or the ambient environment of diagenesis (e.g., C..AUER et al., 1990). As isotopic studies of authigenic material frequently employ a leaching technique, it would be desirable to have independent evidence that leachate and residue are truly cogenetic or are at least genetically related.

If leaching mainly involves the mobilization of cations adsorbed onto clay surfaces or from exchangeable clay interlayer sites, it is difficult to see how these loosely bound cations could "freeze in" an original fluid composition. In order to explain the apparent fractionation of Sm-Nd ratios in claysize separates, AwWILLER and MACK (1991) and Bros et al. (1992) suggested that Nd is incorporated preferentially over $\mathrm{Sm}$ into the clay interlayer sites, resulting in high $\mathrm{Sm}-\mathrm{Nd}$ ratios in the residual fluid. It is unclear, however, whether the partition coefficients of light REEs (LREEs) and middle
REEs (MREEs) in phyllosilicates are sufficiently distinct to cause the observed fractionation. In this study we suggest that apatite, a soluble, accessory phase rich in REEs and frequently present in low-grade sediments, dominates the REE inventory in the leachates and therefore controls fractionation in the system. We also present evidence that REEs in leachates and residues are derived from cogenetic phases, not just by virtue of the meaningful age information, but also related to their complementary REE patterns.

\section{GEOLOGIC BACKGROUND AND SAMPLE DESCRIPTION}

The samples used in this study include Ordovician and Silurian argillaceous rocks from central and northern Wales, an Ordovician turbidite sequence from New York, and a Devonian siltstone unit from New York. Both Lower Paleozoic sequences were deposited in a continental margin setting inboard from a converging island arc system, and the Devonian unit belongs to the sequence of Appalachian foreland sediments that was deposited during the Acadian orogeny. Bentonites and other volcanic products are interlayered with these hemipelagic and turbiditic sediments and provide a precise datum for the well-resolved biostratigraphy (Fig. 1).

The rocks from the Welsh basin were chosen to test the hypothesis that diagenesis and low-grade metamorphism may be dated using the $\mathrm{Sm}-\mathrm{Nd}$ system, and to enhance understanding of the factors that might influence the REE distribution and fractionation in argillaceous sediments. The shales and slates of the Lower Paleozoic Welsh basin were easily accessible and met some basic requirements for this study: the rocks are old enough to have developed measurable differences in their neodymium isotopic composition related to an expected range of ${ }^{147} \mathrm{Sm} /{ }^{144} \mathrm{Nd}$; their depositional ages are well known and precisely bracketed by bentonite U-Pb ages (Fig. 1; TUCKER et al., 1990); they have been mapped in great detail, and their mineralogical and structural properties have been intensively studied (e.g., ROBERTS, 1979; MERRIMAN and ROBERTS, 1985; ROBERTS and MERRIMAN, 1985; BEVINS et al., 1985; MCKERROW, 1988; WOODCOCK et al., 1988). Leaching experiments were conducted on separates of rocks from a range of metamorphic grades, using various size fractions and acids of different strength. In addition to detailed isotopic analyses of the sample fractions, complete REE patterns were measured to establish the nature of the REE carrier phases in leachates and residues.

Two groups of samples from New York were chosen to address questions related to the possibility of subsequent disturbances in the Sm-Nd system. These rocks were sampled adjacent to limestone units that have been associated with fluid migration and widespread remagnetization in the late Paleozoic of North America (MCCABE and ELMORE, 1989). As the isotopic evidence for these events in carbonate rocks is contradictory (e.g., HEARN and SUTTER, 1985; DEWOLF and HALLIDAY, 1991), additional information as to the extent and timing of fuid migration might be gleaned from these adjacent clastic horizons. Building on the detailed study of the Sm-Nd technique for the Welsh suite, the consistency of the technique was further examined by addressing the compatibility of $\mathrm{Sm}-\mathrm{Nd}$ and $\mathrm{Rb}-\mathrm{Sr}$ results for the fine-grained fraction of a single sample (Devonian siltstone). Finally, the utility and limitations of the technique for whole-rock samples were evaluated, using a leachate isochron derived from powdered bulk samples (Ordovician turbiditic shales).

\section{The Lower Paleozoic Rocks of Wales}

The early Paleozoic geology of Wales is dominated by extension and subsequent compression related to the closure of the Iapetus ocean between North America and the Avalon terrane, with Wales representing the Avalonian margin (WoODCOCK et al., 1988). Subsidence continued throughout the Cambrian, characterized by alternating coarse and fine deep-water clastic deposits. In the early Ordovician, uplift and associated island-arc volcanism indicate the transition toward a convergent tectonic setting, which was followed by volcanism and sedimentation related to back-arc extension ( $\mathrm{KO}$ KELAAR et al., 1984). Clastic rocks of the Arenigian transgression 


\section{North American type section Welsh type section (Ordovician)}
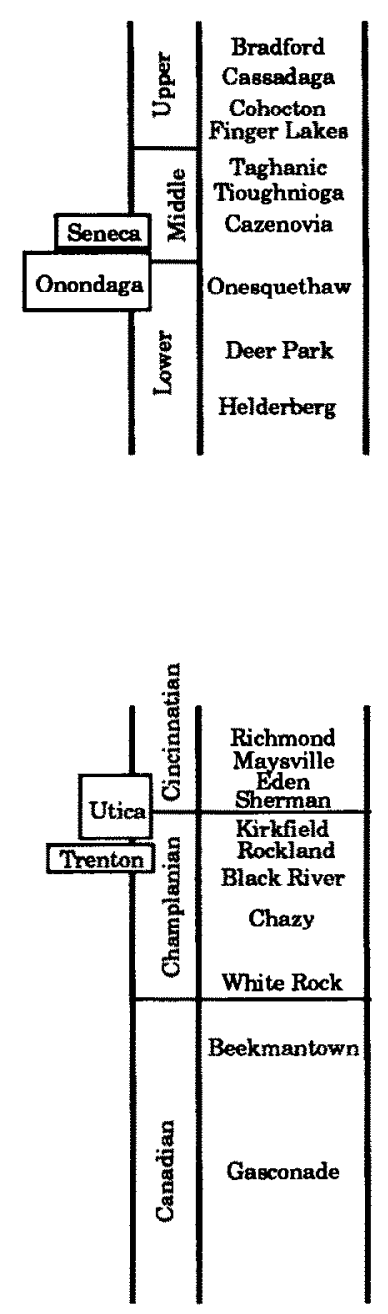

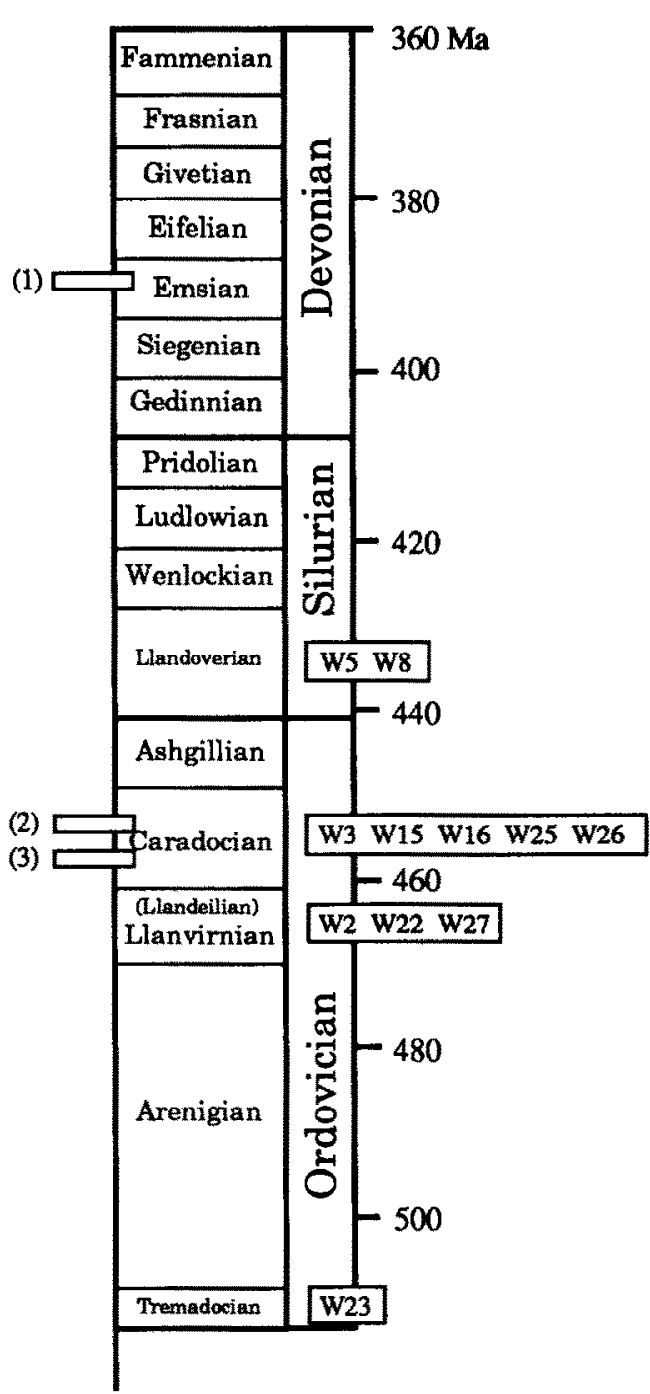

Fig. 1. Stratigraphic type sections of the Ordovician of Wales, and the Ordovician and Devonian of eastern North America. The composite time scale is from HARLAND et al, (1982, 1990) and TUCKER et al. (1990). Markers (1), (2), and (3) represent the ages of the Tioga bentonite (RODEN et al., 1990), a Rocklandian bentonite (TUCKER et al., 1990), and the Deicke bentonite (SAMSON et al., 1989), respectively. The stratigraphic position of all samples is marked by the boxes.

are overlain by Llanvirnian to early Caradocian volcanic rocks of a bimodal basalt-rhyolite association. These volcanic rocks are interlayered with shallow marine siltstones and mudstones. Upper Caradocian and Ashgillian strata consist mainly of argillaceous rocks and black graptolite mudstones and are overlain by Silurian deep water turbidite strata. This overall sequence of events is consistent with the presence of a single, southeast dipping subduction system below the Lake District-Irish arc, with the Welsh basin situated on the crystalline margin of the continent (KOKELAAR et al., 1984; STILLMAN, 1988). Deformation and regional metamorphism occurred during the early to mid-Devonian (MCKERRow, 1988; WOODCOCK et al., 1988), contemporaneous with the emplacement of granites in the Lake District at $394 \pm 3$ Ma (WADGE et al., 1978). In addition, $\mathrm{Rb}-\mathrm{Sr}$ ages of Ordovician and Silurian volcanic rocks appear to be widely reset to approximately $390 \mathrm{Ma}$ (EVANS, 1991). In general, rocks of the Welsh basin were subjected to temperatures of $\angle 350^{\circ} \mathrm{C}$, indicated by mainly prehnite-pumpellyite to pumpellyite- actinolite facies metamorphism in mafic rocks (ROBERTS, 1981; BEviNS et al., 1985). The metamorphic grade of pelites, based on illite crystallinity (BEVINS et al., 1981; MERRIMAN and ROBERTS, 1985), is directly correlated with the occurrence of mafic index minerals, with diagenetic zone $\left(\Delta 2 \theta>0.42^{\circ}\right)$, anchizone $\left(0.26^{\circ}<\Delta 2 \theta\right.$ $\left.<0.42^{\circ}\right)$, and epizone rocks $\left(\Delta 2 \theta<0.26^{\circ}\right)$ corresponding to zeolite, prehnite-pumpellyite, and greenschist facies rocks, respectively. Conodont coloration and graptolite reflectance data also indicate the prevailing low-grade conditions (OLIVER, 1988). Regional metamorphism in the Welsh basin is related to strain-induced recrystallization and thermal doming during early Devonian deformation (MERRIMAN and ROBERTS, 1985; ROBERTS and MERRIMAN, 1985).

A tabular listing of all samples from Wales, including locations, stratigraphic ages, short lithological descriptions, mineral modes of various size fractions derived from X-ray powder diffraction, and white mica crystallinity, is provided in Table 1. Back-scattered electron images shown in Fig. 2 reveal the main textural and compositional 
Table 1. Location and sample description of Welsh rocks

\begin{tabular}{|c|c|c|c|c|c|c|}
\hline Loc. & $\Delta \mathbf{2 \theta}\left({ }^{\circ}\right)$ & Series & Dep. Age in $\mathbf{M a}$ & National Grid Ref. & Lithology & Bulk mineralogy: high to low (XRD) \\
\hline 2 & 0.63 & Llanvimian & $470-464$ & SO 064618 & $\begin{array}{l}\text { black graptolitic shale; no } \\
\text { discemible cleavage }\end{array}$ & $\begin{array}{l}<5 \mu \mathrm{m}: \mathrm{qz}, \text { chl, illite, ab } \\
<0.2 \mu \mathrm{m}: \text { illite, chl, qz }\end{array}$ \\
\hline 3 & & Caradocian & $461-449$ & SO 036663 & expandable bentonite & $<0.2 \mu \mathrm{m}:$ illite,$<\mathrm{ab}$ \\
\hline 5 & 0.21 & Llandoverian & $441-435$ & SN 874648 & $\begin{array}{l}\text { green slaty mudstone, with } \\
\text { apatite nodules; ax. plan. cleav. }\end{array}$ & WR: chl, qz, K-Na mica, musc, ab, ap \\
\hline 8 & 0.30 & Llandoverian & $441-435$ & SN 746093 & $\begin{array}{l}\text { black slate, strong ax. planar } \\
\text { cleavage; minor interlayered } \\
\text { silt and sand }\end{array}$ & $\begin{array}{l}\text { WR: chl, qz, K-Na mica, musc, ab } \\
>1 \mu \mathrm{m} \text { : chl, K-Na mica, musc, qz, ab } \\
<0.2 \mu \mathrm{m} \text { : chl, musc, } \mathrm{K}-\mathrm{Na} \text { mica }\end{array}$ \\
\hline 15 & 0.19 & Caradocian & $461-449$ & SH 572526 & $\begin{array}{l}\text { blue-green roofing slate, with } \\
\text { abundant reduction spots }\end{array}$ & $\begin{array}{l}>1 \mu \mathrm{m}: \text { chl, qz, illite, ab } \\
<0.2 \mu \mathrm{m}: \text { illite, chl, }<q z\end{array}$ \\
\hline 16 & 0.55 & Caradocian & $461-449$ & SH 372353 & $\begin{array}{l}\text { black-gray mudstone; shelly; } \\
\text { very weak cleavage }\end{array}$ & $\begin{array}{l}>1 \mu \mathrm{m}: \mathrm{chl}, \mathrm{K}-\mathrm{Na} \text { mica, musc, ab } \\
<0.2 \mu \mathrm{m}: \text { K-Na mica, chl, musc }\end{array}$ \\
\hline 22 & 0.34 & Llanvimian & $470-464$ & SH 513423 & $\begin{array}{l}\text { lustrous gray slate; detrital } \\
\text { mica on cleavage surfaces }\end{array}$ & $\begin{array}{l}>1 \mu \mathrm{m} \text { : chl, K-Na mica, musc, qz, ab } \\
<0.2 \mu \mathrm{m}: \mathrm{K}-\mathrm{Na} \text { mica, chl, musc }\end{array}$ \\
\hline 23 & 0.21 & Tremadocian & $513-508$ & SH 546395 & $\begin{array}{l}\text { dark gray slate; strong axial } \\
\text { planar cleavage }\end{array}$ & $\begin{array}{l}\text { WR: chl, qz, musc, K-Na mica, ab } \\
<0.2 \mu \mathrm{m} \text { : chl, K-Na mica, musc, qz }\end{array}$ \\
\hline 25 & 0.31 & Caradocian & $461-449$ & SH 614419 & gray slate; anastom. cleavage & \\
\hline 26 & 0.18 & Caradocian & $461-449$ & SH 607438 & $\begin{array}{l}\text { similar to } 25 \text {, silty slate; in } \\
\text { contact zone with mafic sill and } \\
\text { therefore higher grade }\end{array}$ & $\begin{array}{l}\text { WR: chl, K-Na mica, qz, musc, ab } \\
>1 \mu \mathrm{m}: \text { chl, K-Na mica, qz, musc, ab } \\
<0.2 \mu \mathrm{m} \text { : chl, musc, K-Na mica }\end{array}$ \\
\hline 27 & 0.20 & Llanvimian & $470-464$ & SH 653668 & gray roofing slate & \\
\hline
\end{tabular}

The illite crystallinity values are from Merriman and Roberts (1985, 1990 pers. comm.). Merriman and Roberts distinguished between stage I, II, and III pelites $\left(2 \theta>0.43^{\circ} ; 0.26^{\circ}<2 \theta<0.43^{\circ} ; 2 \theta<0.26^{\circ}\right.$, respectively) on the basis of cleavage development, and occurrence of $1 \mathrm{M}_{\mathrm{d}}$ mixed-layer mica, discrete paragonite, $2 \mathrm{M}_{1} \mathrm{~K}$-mica. These metapelite stages are synonymous with the diagenetic zone, the anchizone, and the epizone.

features of the Welsh anchizonal and epizonal rocks. Large chloritemica stacks, commonly $20-200 \mu \mathrm{m}$ in size, are set in a matrix of finer grained chlorite, illite of predominantly $2 \mathbf{M}_{1}$ polytype, $\mathrm{K}$-feldspar, and ribbon quartz (LI et al., 1993). The stacks are frequently deformed, with individual packets of chlorite and mica bent or disrupted. Chlorite and illite in the matrix are both of detrital and diagenetic origin. Penetrative cleavage is developed only in the higher grade samples and is defined by the crystal preferred orientation of the fine-grained matrix minerals. The orientation of contacts between chlorite and mica layers are on average perpendicular to cleavage (Fig. 2a). In lower grade samples, apatite occurs frequently as small euhedral crystals, ranging in size from $\ll 1 \mu \mathrm{m}$ to about $15 \mu \mathrm{m}$. The larger grains occur isolated within the matrix, whereas the smaller grains are also found as inclusions in chlorite and white mica. In general, apatite is more coarsely grained in higher grade rocks, occurring as relatively large, euhedral crystals (Fig. $2 \mathrm{~b}, \mathrm{c}$ ). Other frequent accessory minerals include needle-shaped rutile and rounded grains of pyrite (often in the form of framboids). Quartz, sphene, and pyrite are found in complex intergrowths (Fig. 2d), and in some cases REErich crandallite, $\mathrm{CaAl}_{3}\left(\mathrm{PO}_{4}\right)_{2}(\mathrm{OH})_{5} \cdot \mathrm{H}_{2} \mathrm{O}$, or florencite, $\mathrm{CeAl}_{3}\left(\mathrm{PO}_{4}\right)_{2}(\mathrm{OH})_{6}$ (LeFEBVRE and GaSPaRINI, 1980), occurs intergrown with quartz, rutile, white mica, and monazite (Fig. 2e). Monazite typically has resorbed grain boundaries. TEM observation of the fine fractions reveals in many cases euhedral apatite crystals as small as $0.1 \mu \mathrm{m}$ in size (Fig. 2f).

\section{Paleozoic rocks from New York}

The Onondaga Group is a sequence of coarse- to fine-grained limestones, commonly containing chert, that ranges in thickness from 21 to $50 \mathrm{~m}$ across New York state (OLIVER, 1956; RICK ARD, 1975). Deposited during the Lower Middle Devonian (Eifelian), it separates in time the Lower Devonian carbonates from the Middle Devonian clastic rocks associated with the Acadian orogeny. A suite of uncleaved, gray to green siltstones was collected from a road cut along
US Highway 20, approximately $1 \mathrm{~km}$ east of the Cherry Valley exit, New York, USA. These clastic rocks are part of the uppermost Seneca member of the Onondaga Group and immediately overlie the Tioga ash layers, dated at $390 \pm 1 \mathrm{Ma}$ (RoDEN et al., 1990). Several workers have documented widespread remagnetization developed in early and mid-Paleozoic carbonates on the North American craton, including the Onondaga limestone (KENT, 1985; MCCABE and ELMORE, 1989; SUK et al., 1990). The position of the late Paleozoic paleopoles associated with this chemical remnant magnetization corresponds in time to the Alleghenian orogeny at ca. $300 \mathrm{Ma}$.

Rocks of the Middle Ordovician Utica Formation are comprised of fissile black shales with variable amounts of carbonate cement. The distal basin facies of the Taconic flysch wedge is represented by the synorogenic clastic rocks of the Utica Formation (ROWLEY and KIDD, 1981), which overstepped the underlying Trenton carbonate platform from east to west in several phases, from the early Kirkfieldian to the early Maysvillian of the North American type section (MrTCHELL et al., 1992). Numerous thin bentonite layers occur within the Trenton Limestone as well as the Utica Formation. A bentonite marking the equivalent of the lower boundary of the Trenton Limestone has been dated at $457 \pm 1 \mathrm{Ma}$ using $\mathrm{U}-\mathrm{Pb}$ dating of zircons (SAMSON et al., 1989), and another bentonitc U-Pb age places the Rocklandian Stage at $453.7 \pm 1.8 \mathrm{Ma}$ (TUCKER et al., 1990). The Trenton Limestone itself yielded a ${ }^{238} \mathrm{U}-{ }^{206} \mathrm{~Pb}$ age of $454 \pm 8 \mathrm{Ma}$ (DeWolf and HAlliday, 1991). The Utica Formation together with the underlying Trenton Limestone is therefore equivalent in time to the Middle Caradocian of Britain (Fig. 1). Samples were collected by J. W. Delano, from west to east, in the Harter Hill area (located $10 \mathrm{~km}$ north of Utica, NY, USA), along Canajoharie Creek and Yatesville Creek (located $3 \mathrm{~km}$ south of Canojoharie, NY, USA), and from the Bean Hill area (east of Canajoharie). The sample suite spans the entire thickness of the Utica Formation, from the lower contact with the Trenton and Black River limestones to the transitional facies of the upper Utica Formation grading into the turbidites of the Schenectady Formation. Paleomagnetic results in the limestones are identical to those for the Onondaga Group, in that late Paleozoic 
pole positions in the Trenton Group post-date deposition by $150 \mathrm{Ma}$ to $200 \mathrm{Ma}$ (MCCABE et al., 1984).

\section{ANALYTICAL TECHNIQUES}

Depending on its degree of lithification, each sample was first disaggregatcd manually in a mortar, or crushed to sand sizc in a jawcrusher, and then passed through a disk-mill grinder. After each step the crushed particles were passed through a 50 mesh $(300 \mu$ m equivalent) sieve to avoid overcrushing. This was followed by continued disaggregation in distilled water, using an orbital shaking table. The resulting slurry was transferred to graduated cylinders and the desired size separates (equivalent spherical diameters) were obtained by applying Stoke's law over a uniform settling distance; flocculation was usually not a problem. The $<0.2 \mu \mathrm{m}$ fraction was separated from the coarser particles using a table-mounted centrifuge at medium speed, and then settled using a high-speed centrifuge. Separate weights that were obtained were typically on the order of only a few hundred milligrams: in some instances this amount proved too small to ensure homogeneity of the separate, so that analyses of different aliquots of the same sample were not always reproducible.

All isotopic composition and isotope dilution measurements were performed in the Radiogenic Isotope Geochemistry Laboratory at the University of Michigan. Typical sample weights for phyllosilicate separates prior to leaching were $10-60 \mathrm{mg}$, depending on the amount of sample available and the expected concentrations. Leachate and clay residue were separated by centrifuging, and the residue was rinsed repeatedly with deionized water. The first and second wash was usually added to the leachate. Residues were digested in a mixture of concentrated distilled $\mathrm{HF}, \mathrm{HClO}_{4}$, and $\mathrm{HNO}_{3}$. Total procedure blanks were somewhat variable, but are always less than $150 \mathrm{pg}$ for $\mathrm{Sr}$, and less than $50 \mathrm{pg}$ for $\mathrm{Nd}$. The higher blanks were typically associated with the use of larger amounts of perchloric acid. Ratios of ${ }^{87} \mathrm{Rb} /$ ${ }^{86} \mathrm{Sr}$ and ${ }^{147} \mathrm{Sm} /{ }^{144} \mathrm{Nd}$ were determined by isotope dilution, using mixed ${ }^{87} \mathrm{Rb}^{-{ }^{84}} \mathrm{Sr}$, and ${ }^{149} \mathrm{Sm}-{ }^{150} \mathrm{Nd}$ spikes. The ${ }^{87} \mathrm{Rb} /{ }^{86} \mathrm{Sr}$ ratios are accurate to better than $1 \%$, and ${ }^{147} \mathrm{Sm} /{ }^{144} \mathrm{Nd}$ ratios to approximately $0.1 \%$. All REE abundances were determined by isotope dilution, using a mixed Ba-rare earth spike. Most ${ }^{87} \mathrm{Sr} /{ }^{86} \mathrm{Sr}$ ratios were determined on totally spiked aliquots, whereas most ${ }^{143} \mathrm{Nd} /{ }^{144} \mathrm{Nd}$ ratios were measured using unspiked aliquots. The strontium isotopic ratios measured on spiked aliquots were corrected for the Sr composition of the spike, with the correction never exceeding +0.000020 . Details of ion exchange and mass spectrometric procedures can be found in HaLLIDAY et al. (1989). Mass spectrometric measurements were performed on two V. G. Sector multicollector thermal ionization mass spectrometers, yielding compatible standard values of 0.710250 \pm 11 for the ${ }^{87} \mathrm{Sr} /{ }^{86} \mathrm{Sr}$ of NBS SRM $987(n=61)$, and 0.511858 $\pm 9\left(\epsilon_{(\mathrm{Nd})}=-15.2 \pm 0.2\right)$ for the ${ }^{143} \mathrm{Nd} /{ }^{144} \mathrm{Nd}$ of La Jolla $(n=39)$. These uncertainties for the standards are expressed as two standard deviations $(2 \sigma)$ from the mean.

\section{RESULTS}

\section{Samples from Wales, UK}

The Sm-Nd and Rb-Sr data for Middle Ordovician and Lower Silurian shales from Wales are summarized in Tables 2 through 4 and in Fig. 3. Leaching of fine-grained separates produces an acid-soluble component (leachates) with high ${ }^{147} \mathrm{Sm} /{ }^{144} \mathrm{Nd}(0.09$ to 0.24$)$, and an acid-insoluble component (residues) with low ${ }^{147} \mathrm{Sm} /{ }^{144} \mathrm{Nd}(0.07$ to 0.14$)$. All leachates from samples corresponding to the diagenetic zone and the anchizone are characterized by higher Sm-Nd ratios and define a linear trend the slope of which is proportional to an age of ca. $460 \mathrm{Ma}$ (Fig. 3a). This indicates that a population of early diagenetic phases with a narrow range of initial neodymium isotopic compositions $\left(\epsilon_{(\mathrm{Nd}) 460 \mathrm{Ma}}=-6\right.$ to -7$)$ was dissolved. In contrast, data for the residual phyllosilicates display more scatter, yet individual leachate-residue tie-lines of the $<0.2 \mu \mathrm{m}$ fraction frequently correspond within error to apparent ages that are transitional between the time of deposition (449-470 Ma) and the time of regional metamorphism (ca. $390 \mathrm{Ma}$ ). The results for leachates and residues of the epizonal samples are distinctly different compared to the lower-grade rocks, showing a much narrower range of $\mathrm{Sm}-\mathrm{Nd}$ ratios and generally less radiogenic Nd.

The $\mathrm{Rb}-\mathrm{Sr}$ results shown in Fig. 3b were obtained from two illite-rich, black mudstone samples (Llanvirnian to Caradocian, diagenetic zone), and from one chlorite-rich, turbidite mudstone sample (Llandoverian, epizone) containing apatite concretions. Data for the chlorite-rich assemblage plot within mid-Ordovician (460 Ma) to early Silurian (430 Ma) reference isochrons, but the results for the illite-dominated assemblage scatter widely. The leachate data in particular are problematic, having high $\mathrm{Rb}-\mathrm{Sr}$ ratios and very radiogenic $\mathrm{Sr}$, and leachate-residue tie-lines do not provide any meaningful age information.

We observe three important correlations between $\mathrm{Sm}-\mathrm{Nd}$ isotopic data and mineralogical or textural parameters. In the order of discussion below, these are the grain-size dependence of two-point leachate-residue ages (L-R ages), the grainsize dependence of $\mathrm{Sm}-\mathrm{Nd}$ ratios and of element abundances, and the dependence of ages on metamorphic grade.

\section{The grain size dependence of leachate-residue ages}

In general, smaller size fractions yield younger two-point leachate-residue (L-R) ages (Fig. 4). These ages are calculated in the same fashion as two-point $\mathrm{Sm}-\mathrm{Nd}$ isochrons:

$$
\begin{aligned}
& \text { age }=1 / \lambda_{\mathrm{Nd}} \\
& * \ln \left[\left(\Delta_{\mathrm{L}-\mathrm{R}}{ }^{143} \mathrm{Nd} / /^{144} \mathrm{Nd} / \Delta_{\mathrm{L}-\mathrm{R}}{ }^{147} \mathrm{Sm} /{ }^{144} \mathrm{Nd}\right)+1\right] .
\end{aligned}
$$

We analyzed a series of size fractions of the Llanvirnian black mudstone $\mathrm{W} 2 \mathrm{a}$, ranging from $<5 \mu \mathrm{m}$ to $<0.2 \mu \mathrm{m}$. The stratigraphic age of the Llanvirnian is bracketed between 470 $\mathrm{Ma}$ and $464 \mathrm{Ma}$ at maximum uncertainty (TUCKER et al., 1990). The $<5 \mu \mathrm{m}$ fraction yields ages of $496 \pm 24 \mathrm{Ma}$ and $502 \pm 29 \mathrm{Ma}$, the $<1 \mu \mathrm{m}$ fraction yields ages of $480 \pm 22$ $\mathrm{Ma}$ and $456 \pm 28 \mathrm{Ma}$, and the $<0.2 \mu \mathrm{m}$ fraction has ages of $453 \pm 22 \mathrm{Ma}$ and $473 \pm 29 \mathrm{Ma}$, for leaching procedures using $1 \mathrm{~N}$ hydrochloric acid and $10 \%$ acetic acid, respectively. Other coarse splits include sample W25 $(<10 \mu \mathrm{m})$ with an apparent age of $627 \pm 35 \mathrm{Ma}$, and sample W27.3 $(<5 \mu \mathrm{m})$ with an apparent age of $574 \pm 26 \mathrm{Ma}$. The uncertainties of these values are related mainly to the difference in $\mathrm{Sm}-\mathrm{Nd}$ ratio between leachate and residue. Clearly the coarse fractions yield apparent ages in excess of the depositional age. However, the $<1 \mu \mathrm{m}$ and the $<0.2 \mu \mathrm{m}$ ages are concordant and consistent with the depositional age.

In the marginal basin setting of the Lower Paleozoic of Wales, the relative contributions of younger volcanic sources and older cratonic sources can be extremely variable over a short time scale (THOROGOOD, 1990). Consequently, the initial isotopic composition of any one sedimentary unit is expected to be variable as well. This isotopic heterogeneity due to variable source characteristics highlights the importance of a single sample approach to the dating of sedimentary processes. 


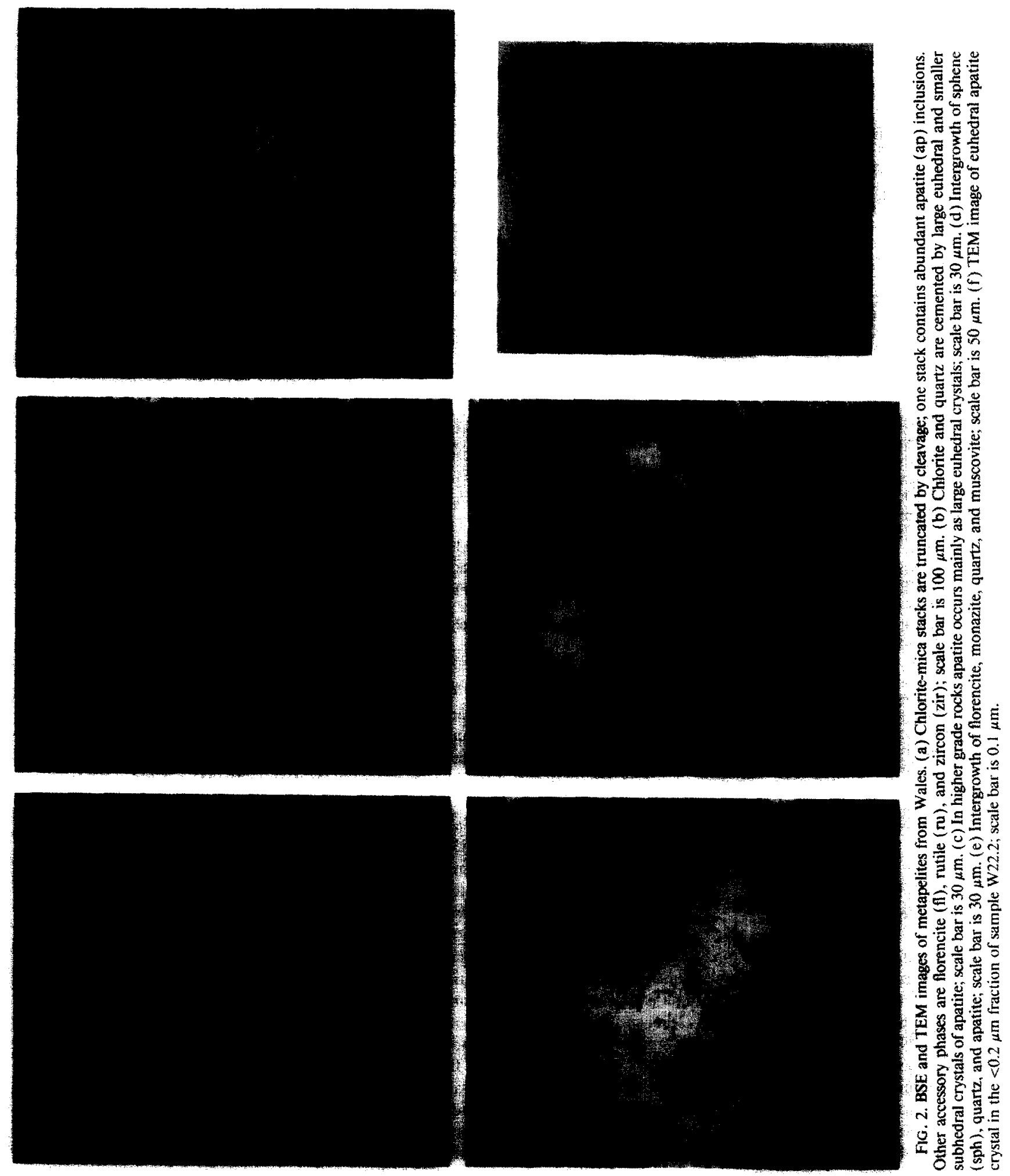



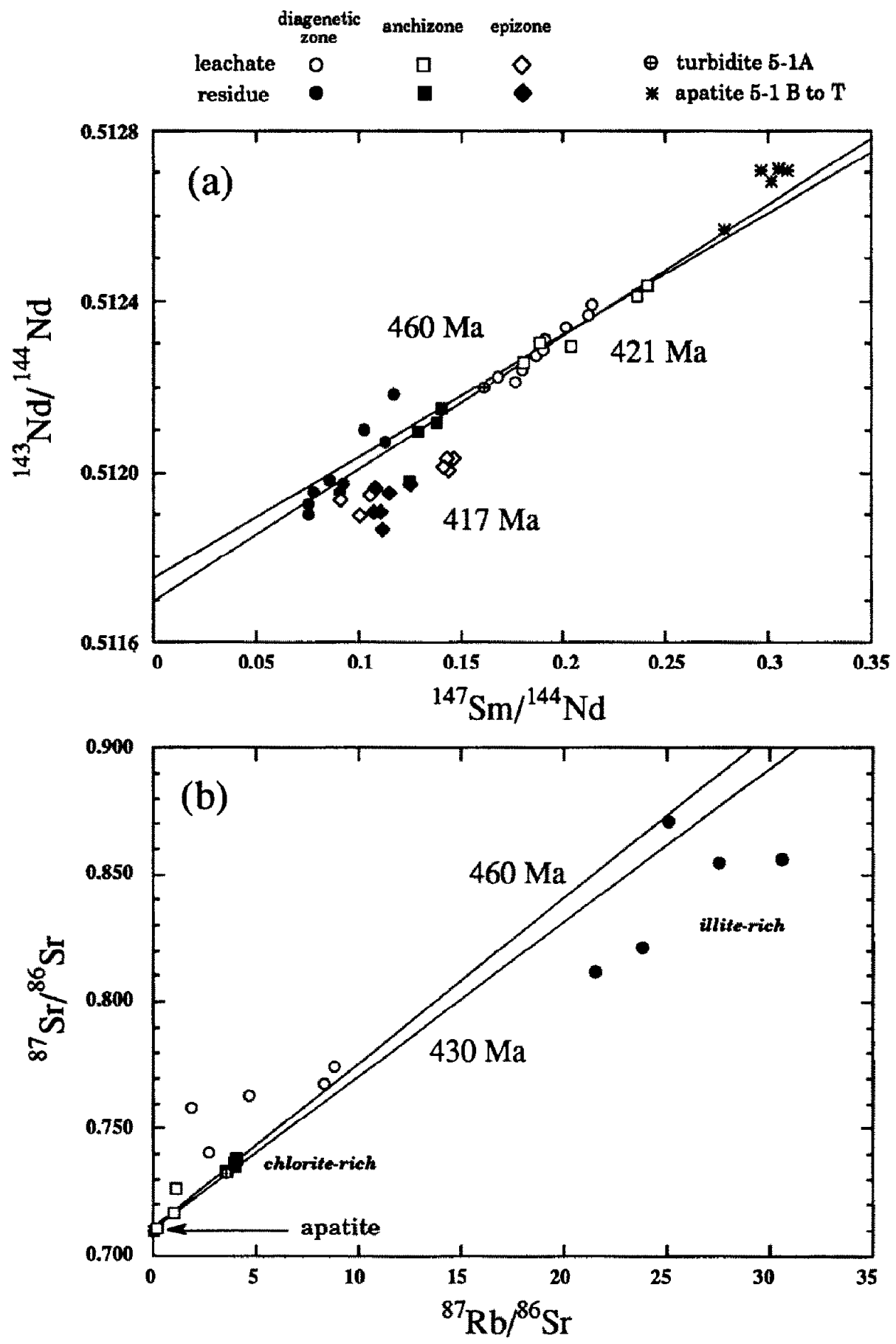

Fig. 3. Sm-Nd and Rb-Sr results for all Welsh rocks. (a) ${ }^{147} \mathrm{Sm} /{ }^{144} \mathrm{Nd}$ vs. ${ }^{143} \mathrm{Nd} /{ }^{144} \mathrm{Nd}$ plot; the Ordovician $460 \mathrm{Ma}$ reference line $\left(\epsilon_{(\mathrm{Nd}) t}=-6.5\right)$ includes all diagenetic and anchizonal leachates. The $421 \mathrm{Ma}$ line is regressed through the data of W22,2 (anchizone). All epizonal rocks are less fractionated and have less radiogenic Nd. (b) ${ }^{87} \mathrm{Rb} /{ }^{86} \mathrm{Sr} \mathrm{vs}$. ${ }^{87} \mathrm{Sr} /{ }^{86} \mathrm{Sr}$ plot; residue and leachate data of diagenetic, illite-rich samples (Llanvirnian to Caradocian; circles) are discordant. Data for an anchizonal, chlorite-rich sequence (Llandoverian; squares) are consistent with the stratigraphic age of about $430 \mathrm{Ma}$.

The grain size dependence of $S m-N d$ ratios and $R E E$ concentrations

The untreated sample $\mathrm{W} 2 \mathrm{a}$ exhibits higher $\mathrm{Sm}-\mathrm{Nd}$ ratios in the coarser size fractions. The ${ }^{147} \mathrm{Sm} /{ }^{144} \mathrm{Nd}$ ratios decrease from 0.101 to 0.0996 to 0.0922 for the $<5 \mu \mathrm{m},<1 \mu \mathrm{m}$, and $<0.2 \mu \mathrm{m}$ size split, respectively. The Sm and Nd concentrations of the $<5 \mu \mathrm{m}$ and $<1 \mu \mathrm{m}$ sample are similar, yet are much higher than those of the $<0.2 \mu \mathrm{m}$ sample. All data in Table 2 are calculated in such a way that Sm and Nd abun- 
Table 2. Sm-Nd and Rb-Sr isotopic results for samples from Wales

\begin{tabular}{|c|c|c|c|c|c|c|c|}
\hline Sample & $S m^{b}$ & $N d^{b}$ & ${ }^{147} \mathrm{Sm} / 144 / \mathrm{Nd}^{\mathrm{c}}$ & ${ }^{143} \mathrm{Nd} / /^{144} \mathrm{Nd}^{\mathrm{d}}$ & EN(a) & $\mathbf{t}(\mathrm{L}-\mathrm{R}) \mathbf{c}$ & $\Delta 2 \theta^{f}$ \\
\hline 2a $5 \mu R H$ & 3.568 & 28.27 & 0.076270 & $0.511899(10)$ & -14.4 & 496 & 0.63 \\
\hline 2a $5 \mu \mathrm{LH}$ & 2.641 & 8.859 & 0.18083 & $0.512239(13)$ & -7.8 & & \\
\hline 2a $5 \mu R A$ & 5.219 & 33.86 & 0.093217 & $0.511972(10)$ & -13.0 & 502 & \\
\hline $2 a 5 \mu \mathrm{LA}$ & 1.121 & 4.011 & 0.16890 & $0.512221(10)$ & -8.1 & & \\
\hline $2 a 5 \mu \mathrm{U}$ & 6.617 & 39.59 & 0.10104 & $0.512026(10)$ & -11.9 & & \\
\hline 2a $1 \mu R H$ & 3.646 & 28.76 & 0.076525 & $0.511922(10)$ & -14.0 & 480 & \\
\hline 2a $1 \mu \mathrm{LH}$ & 2.034 & 6.560 & 0.18751 & 0.512271 (12) & -7.2 & & \\
\hline $221 \mu \mathrm{RA}$ & 4.935 & 32.58 & 0.091622 & $0.511952(10)$ & -13.4 & 456 & \\
\hline 2a $1 \mu \mathrm{LA}$ & 0.7543 & 2.569 & 0.17740 & 0.512208 (15) & -8.4 & & \\
\hline $2 a 1 \mu \mathrm{U}$ & 6.572 & 39.89 & 0.099573 & $0.512013(10)$ & -12.2 & & \\
\hline $2 \pi 0.2 \mu R H$ & 1.928 & 14.88 & 0.078371 & $0.511950(10)$ & -13.4 & 453 & \\
\hline 2a $0.2 \mu \mathrm{LH}$ & 0.7542 & 2.393 & 0.19051 & 0.512283 (13) & -6.9 & & \\
\hline 2. $0.2 \mu \mathrm{RA}$ & 1.813 & 12.70 & 0.08625 & $0.511980(11)$ & -12.8 & 473 & \\
\hline $2 \mathrm{a} 0.2 \mu \mathrm{LA}$ & 0.2989 & 0.9435 & 0.19152 & $0.512306(17)$ & -6.5 & & \\
\hline $2 a 0.2 \mu U$ & 2.331 & 15.29 & 0.092175 & $0.512033(23)$ & -11.8 & & \\
\hline $8.10 .2 \mu \mathrm{R} \mathrm{A}$ & 3.374 & 14.84 & 0.13751 & $0.512156(10)$ & -9.3 & 430 & 0.30 \\
\hline $8.10 .2 \mu \mathrm{L} \mathrm{A}$ & 0.8171 & 2.620 & 0.18864 & $0.512300(10)$ & -6.6 & & \\
\hline $15.30 .2 \mu R A$ & 5.600 & 29.19 & 0.11596 & $0.511950(10)$ & -13.4 & 413 & 0.19 \\
\hline $15.30 .2 \mu \mathrm{L} \mathrm{A}$ & 0.4841 & 1.996 & 0.14663 & $0.512033(10)$ & -11.8 & & \\
\hline $16.10 .2 \mu \mathrm{R} \mathrm{H}$ & 0.9606 & 4.928 & 0.11784 & $0.512179(12)$ & -9.0 & 334 & 0.55 \\
\hline $16.10 .24 \mathrm{LH}$ & 0.5129 & 1.447 & 0.21434 & $0.512390(10)$ & -4.8 & & \\
\hline $16.20 .2 \mu$ R A & 1.873 & 10.00 & 0.11320 & $0.512068(10)$ & -11.1 & 459 & 0.55 \\
\hline $16.20 .2 \mu \mathrm{LA}$ & 0.5354 & 1.524 & 0.21238 & $0.512366(15)$ & -5.3 & & \\
\hline $16.20 .2 \mu$ R H & 0.9509 & 5.563 & 0.10333 & $0.512101(10)$ & -10.5 & 368 & \\
\hline $16.20 .2 \mu \mathrm{LH}$ & 0.6442 & 1.934 & 0.20135 & $0.512337(10)$ & -5.9 & & \\
\hline $22.20 .2 \mu R A$ & 1.948 & 8.404 & 0.14009 & $0.512148(10)$ & -9.6 & 422 & 0.34 \\
\hline $22.20 .2 \mu \mathrm{LA}$ & 0.2111 & 0.5410 & 0.23600 & $0.512413(15)$ & -4.4 & & \\
\hline $22.20 .2 \mu \mathrm{R}$ AH & 2.353 & 11.03 & 0.12905 & $0.512096(10)$ & -10.6 & & \\
\hline $22.20 .2 \mu \mathrm{LA}$ & 0.3040 & 0.7606 & 0.24163 & $0.512425(15)$ & -4.2 & 421 & \\
\hline $22.20 .2 \mu \mathrm{LH}$ & 0.5078 & 1.698 & 0.18084 & $0.512257(11)$ & -7.4 & & \\
\hline $23.20 .2 \mu \mathrm{RA}$ & 6.251 & 34.66 & 0.10898 & $0.511962(10)$ & -13.2 & $\ldots$ & 0.21 \\
\hline $23.20 .2 \psi \mathrm{LA}$ & 5.942 & 33.73 & 0.10648 & $0.511944(10)$ & -13.5 & & \\
\hline $2510 \mu R A$ & 3.561 & 17.25 & 0.12467 & $0.511967(10)$ & -12.9 & 627 & 0.38 \\
\hline $2510 \mu \mathrm{LA}$ & 0.6906 & 2.051 & 0.20373 & $0.512292(10)$ & -6.8 & & \\
\hline $260.2 \mu \mathrm{R} \mathrm{A}$ & 3.453 & 16.52 & 0.12610 & $0.511974(10)$ & -13.8 & --- & 0.18 \\
\hline $260.2 \mu \mathrm{LA}_{\mathrm{A}}$ & 1.680 & 11.01 & 0.092051 & $0.511931(10)$ & -13.0 & & \\
\hline $27.35 \mu$ R A & 3.497 & 19.04 & 0.11105 & $0.511904(10)$ & -14.3 & 574 & 0.20 \\
\hline $27.35 \mu \mathrm{LA}$ & 0.1171 & 0.4908 & 0.14404 & $0.512028(15)$ & -11.9 & & \\
\hline $27.40 .2 \mu$ R A & 4.506 & 25.12 & 0.10834 & $0.511903(10)$ & -14.9 & 421 & 0.20 \\
\hline $27.40 .2 \mu \mathrm{L} \mathrm{A}$ & 0.1669 & 0.7002 & 0.14434 & $0.512002(16)$ & -11.9 & & \\
\hline $27.40 .2 \mu$ R AH & 3.028 & 16.30 & 0.11227 & $0.511865(10)$ & -15.1 & & \\
\hline $27.40 .2 \mu \mathrm{L} \mathrm{A}$ & 0.1312 & 0.5550 & 0.14220 & $0.512009(10)$ & -12.3 & 417 & \\
\hline $27.40 .2 \mu \mathrm{L} \mathrm{H}$ & 1.511 & 9.017 & 0.10120 & 0.511897 (11) & -14.5 & & \\
\hline \multirow[t]{2}{*}{$27.40 .2 \mu \mathrm{U}$} & 5.336 & 28.73 & 0.11226 & $0.511879(10)$ & -14.8 & & \\
\hline & $\mathbf{R b}$ & Sr & ${ }^{87} \mathrm{Rb} / 86 \mathrm{Sr}^{2}$ & ${ }^{87} \mathrm{Sr}^{86} \mathrm{Sr}^{\mathrm{h}}$ & & & \\
\hline $2 \pi 0.2 \mu \mathrm{RH}$ & 249.4 & 33.60 & 21.56 & $0.81157(5)$ & & 201 & 0.63 \\
\hline $2.0 .2 \mu \mathrm{LH}$ & 6.327 & 3.929 & 4.668 & $0.76331(6)$ & & & \\
\hline $2 \mathrm{a} 0.2 \mu \mathrm{RA}$ & 231.3 & 28.19 & 23.86 & $0.82153(3)$ & & 200 & \\
\hline $20.2 \mu \mathrm{LA}_{\mathrm{A}}$ & 1.865 & 2.897 & 1.863 & $0.75890(6)$ & & & \\
\hline
\end{tabular}


Table 2. (Continued)

\begin{tabular}{|c|c|c|c|c|c|c|}
\hline & $\mathbf{R b}$ & Sr & ${ }^{87} \mathrm{Rb} \mathrm{p}^{\beta 6} \mathrm{~S} \mathrm{r}^{4}$ & ${ }^{87} \mathrm{Sr} / 66 \mathrm{~S} \mathrm{r}^{h}$ & & \\
\hline $16.10 .2 \mu \mathrm{R} \mathrm{H}$ & 278.9 & 29.48 & 27.59 & $0.85489(4)$ & 298 & 0.55 \\
\hline $16.10 .2 \mu \mathrm{LH}$ & 5.917 & 1.959 & 8.782 & $0.77504(4)$ & & \\
\hline $16.20 .2 \mu \mathrm{RH}$ & 238.2 & 27.74 & 25.11 & $0.87132(3)$ & 430 & 0.55 \\
\hline $16.20 .2 \mu \mathrm{LH}$ & 7.132 & 2.502 & 8.273 & $0.76822(9)$ & & \\
\hline $16.20 .2 \mu$ RA & 306.4 & 29.29 & 30.60 & $0.85612(3)$ & 290 & \\
\hline $16.20 .2 \mu \mathrm{LA}$ & 2.155 & 2.333 & 2.669 & $0.74069(6)$ & & \\
\hline $2510 \mu \mathrm{RA}$ & 171.3 & 142.8 & 3.464 & 0.73393 & 212 & 0.38 \\
\hline $2510 \mu L A$ & 1.246 & 3.311 & 1.082 & $0.72675(5)$ & & \\
\hline
\end{tabular}

(a): $U=$ untreated sample; $L=$ leachate; $R=$ residue after leaching. $A=$ acetic acid leach; $\mathrm{H}=\mathrm{IN} \mathrm{HCl}$ leach; $\mathrm{AH}=$ sequential acetic acid and $\mathrm{HCl}$ leach. (b): All concentrations are calculated relative to pre-leaching weight: hence $[L]+[R]=[U]$ in ppm. (c): Error $\leq 0.1 \%$. (d): normalized to ${ }^{146} \mathrm{Nd} / 14 \mathrm{Nd}=0.7219$; minimum error $=0.000009$ (20), given by La Jolla ${ }^{143} \mathrm{Nd} / 14_{\mathrm{Nd}}=0.511858$ (9). (e): leachate - residue age in Ma. (f): illite crystallinity in degrees

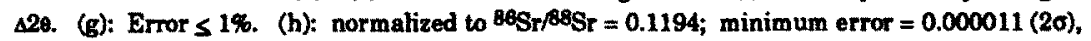
given by NBS $98787 \mathrm{Sr} / 6 \mathrm{Sr}=0.710250$ (11).

dances for leachate and residues can be reintegrated to the untreated concentrations by simple addition. In Fig. $5 a, b$ the measured and reintegrated $\mathrm{Sm}-\mathrm{Nd}$ ratios and concentrations for W2a are compared. The variability of measured vs. reintegrated Sm-Nd ratio in the finer fractions is most likely related to the heterogeneity of the separates. The $<5 \mu \mathrm{m}$ split is the most voluminous and the reintegrated $\mathrm{Sm}-\mathrm{Nd}$ ratio is within $<0.1 \%$ of the measured ratio, whereas the homogeneity of the finer fractions is probably compromised by the small yield of sample preparation.

There is an additional relationship between grain size and the proportion of leached $\mathrm{Sm}$ and $\mathrm{Nd}$ relative to the total concentrations. The $1 \mathrm{~N}$ HCl leachate contains $42.5 \%, 35.8 \%$, and $28.1 \%$ of all $\mathrm{Sm}$, and $23.9 \%, 18.6 \%$, and $14.0 \%$ of all $\mathrm{Nd}$, where the percentages correspond to decreasing grain size. For the acetic acid leachate the proportions are $17.7 \%$, $13.3 \%$, and $14.2 \%$ of the total $\mathrm{Sm}$, and $10.6 \%, 7.3 \%$, and $6.9 \%$ of the total Nd. Thus, the smaller the grain size, the less $\mathrm{Sm}$ and Nd of the total REE inventory is partitioned into the leachate. However, the leachates have generally higher $\mathrm{Sm}-\mathrm{Nd}$ ratios with decreasing grain size (Fig. $5 \mathrm{c}, \mathrm{d}$ ). If the REE ratios and abundances in the leachates are controlled by the occurrence of soluble, REE-enriched phases in the sediment, then coarser splits contain soluble phases with a lower integrated $\mathrm{Sm} / \mathrm{Nd}$, but a higher REE concentration. In contrast, finer splits are characterized by the occurrence of soluble phases with higher integrated $\mathrm{Sm} / \mathrm{Nd}$, yet lower overall REE concentrations. This general pattern is consistent with SEM observations of these rocks, indicating that the larger grains of accessory phases (usually $>5 \mu \mathrm{m}$ ) are mainly LREE-enriched monazite and florencite, whereas the smaller grains (generally $\ll 5 \mu \mathrm{m}$ ) include abundant crystals of apatite. With decreasing grain size, LREE-enriched monazite and florencite become less abundant, and the REE budget in the leachate is increasingly dominated by a MREE-enriched phase such as apatite. The correlation between grain size, abundance pattern of soluble, accessory phases, and Sm-Nd systematics in the leachates is important. It points toward the crucial role that is played by accessory phases in controlling the REE distribution in pelitic rocks.

\section{The dependence of Sm-Nd ages on metamorphic grade}

The quasilinear relation between two-point leachate-residue ages (L-R ages) of $<0.2 \mu \mathrm{m}$ samples and metamorphic grade is shown in Fig. 6. Samples from the diagenetic zone yield ages indistinguishable from their depositional ages: in addition to the data for sample W2a discussed above, the gray Caradocian mudstone W16.2 yields an age of $459 \pm 28$ $\mathrm{Ma}$ ( the series boundaries of the Caradocian are 461 to 449 Ma; TUCKER et al., 1990). Leaching with acetic acid frequently gives different results from those obtained using $\mathbf{H C l}$. For example, both $\mathrm{HCl}$ residues for $\mathrm{W} 16.1$ and $\mathrm{W} 16.2$ have high ${ }^{143} \mathrm{Nd} /{ }^{144} \mathrm{Nd}$, resulting in ages that are anomalously young by as much as $100 \mathrm{Ma}$. While uncertain how to explain this phenomenon, we do observe that the $\mathrm{HCl}$ leachates are collinear with the L-R tie lines produced by leaching with acetic acid. Samples with lower illite crystallinities, corresponding to the anchizone and epizone, such as W22.2, W8.1, W15.3, and W27.4 yield lower Sm-Nd ages, between 413 and $430 \mathrm{Ma}$ (Table 2). The anchizonal sample W22.2 is particularly well constrained: data for a sequential acetic acid$\mathrm{HCl}$ leach and an independently performed acetic acid procedure are collinear in a Sm-Nd plot, corresponding to an age of $421 \pm 8 \mathrm{Ma}$. The ages for these anchizonal and epizonal samples are intermediate between their stratigraphic age and the timing of regional metamorphism at $390 \mathrm{Ma}$. Finally, the difference in Sm-Nd ratio between leachate and residue is small or nonexistent in most samples with illite maturities corresponding to the epizone (Table 2), and in two instances the leachates have slightly lower Sm-Nd ratios than the corresponding residues. 
Table 3. Rare earth isotope dilution data for Welsh rocks and Gulf Coast sample ZB 11.

\begin{tabular}{|c|c|c|c|c|c|c|c|c|c|c|c|}
\hline Sample & $\mathbf{L a}^{\mathbf{b}}$ & $\mathrm{Ce}$ & Nd & $\mathrm{Sm}$ & $\mathrm{Eu}$ & Gd & Dy & Er & $\mathrm{Yb}$ & Lu & $\mathrm{Sm} / \mathrm{Nd}$ \\
\hline \multicolumn{12}{|c|}{ ZB 11 (Zula Boyd well, Texas Gulf Coast) } \\
\hline $\begin{array}{l}\text { WR } 1 \text { (PFA) } \\
\text { WR } 2 \text { (bomb) }\end{array}$ & $\begin{array}{l}34.4 \\
30.8\end{array}$ & $\begin{array}{l}75.3 \\
72.0\end{array}$ & $\begin{array}{l}33.5 \\
29.7\end{array}$ & $\begin{array}{l}6.18 \\
5.75\end{array}$ & $\begin{array}{l}1.31 \\
1.23\end{array}$ & $\begin{array}{l}5.33 \\
5.20\end{array}$ & $\begin{array}{l}4.75 \\
4.63\end{array}$ & $\begin{array}{l}2.72 \\
2.65\end{array}$ & $\begin{array}{l}2.59 \\
2.47\end{array}$ & $\begin{array}{l}0.410 \\
0.373\end{array}$ & $\begin{array}{l}0.1845 \\
0.1936\end{array}$ \\
\hline$<0.1 \mu \mathrm{L}$ water & 0.0609 & 0.141 & 0.0897 & 0.0256 & 0.00693 & 0.0339 & 0.0287 & 0.0144 & 0.0181 & 0.00358 & 0.2854 \\
\hline$<0.1 \mu$ L AcAcid & 0.0713 & 0.584 & 0.271 & 0.113 & 0.0308 & 0.135 & 0.0798 & 0.0298 & 0.0240 & 0.00368 & 0.4170 \\
\hline$<0.1 \mu \mathrm{L} \mathrm{HCl}$ & 1.62 & 4.71 & 2.95 & 0.928 & 0.254 & 1.20 & 0.918 & 0.355 & 0.255 & 0.0364 & 0.3146 \\
\hline$<0.1 \mu \mathrm{R}$ & 18.3 & 31.9 & 10.3 & 1.42 & 0.265 & 0.995 & 1.45 & 1.13 & 1.13 & 0.172 & 0.1379 \\
\hline$<0.1 \mu \mathrm{U}$ calc $\mathrm{c}$ & 20.05 & 37.34 & 13.61 & 2.487 & 0.5567 & $\overline{2.364}$ & 2.476 & 1.529 & 1.427 & 0.2157 & 0.1827 \\
\hline$<0.1 \mu \mathrm{L} \mathrm{HCl}$ & & & 3.33 & 1.04 & & & & & & & 0.3123 \\
\hline$<0.1 \mu R$ & & & 10.8 & 1.45 & & & & & & & 0.1343 \\
\hline$<0.1 \mathrm{~m} \mathrm{U}$ calc $c$ & & & 14.13 & 2.49 & & & & & & & 0.1762 \\
\hline$<0.1 \mu \mathrm{U}^{\mathrm{d}}$ & 17.2 & 33.8 & 11.7 & 2.13 & 0.475 & 2.03 & 2.15 & 1.34 & 1.25 & 0.186 & 0.1821 \\
\hline \multicolumn{12}{|c|}{ W 22.2 (Llyn Peninsula, Wales) } \\
\hline $\begin{array}{l}\text { WR } 1 \text { (PFA) } \\
\text { WR } 2 \text { (bomb) }\end{array}$ & $\begin{array}{l}51.2 \\
50.5\end{array}$ & $\begin{array}{c}99.5 \\
101\end{array}$ & $\begin{array}{l}44.2 \\
45.0\end{array}$ & $\begin{array}{l}8.18 \\
8.07\end{array}$ & $\begin{array}{l}1.71 \\
1.68\end{array}$ & $\begin{array}{l}6.93 \\
6.92\end{array}$ & $\begin{array}{l}6.13 \\
5.97\end{array}$ & $\begin{array}{l}3.51 \\
3.24\end{array}$ & $\begin{array}{l}3.25 \\
2.90\end{array}$ & $\begin{array}{l}0.489 \\
0.426\end{array}$ & $\begin{array}{l}0.1851 \\
0.1793\end{array}$ \\
\hline$<0.2 \mu$ L AcAcid & 0.190 & 0.731 & 0.761 & 0.304 & 0.0790 & 0.367 & 0.211 & 0.0715 & 0.0410 & 0.00487 & 0.3995 \\
\hline$<0.2 \mu \mathrm{L} \mathrm{HCl}$ & 1.02 & 3.68 & 1.70 & 0.508 & 0.123 & 0.580 & 0.386 & 0.151 & 0.109 & 0.0151 & 0.2998 \\
\hline$<0.2 \mu \mathrm{R}$ & 24.9 & 24.7 & 11.0 & 2.35 & 0.550 & 2.16 & 2.23 & 1.720 & 2.29 & 0.387 & 0.2136 \\
\hline$<0.2 \mu \mathrm{U}$ calc.c & 26.11 & 29.11 & 13.46 & 3.162 & 0.7520 & 3.107 & 2.827 & 1.943 & 2.440 & 0.4070 & 0.2349 \\
\hline$<0.2 \psi \mathrm{L}$ AcAcid & & & 0.541 & 0.217 & & & & & & & 0.4011 \\
\hline$<0.2 \mu \mathrm{R}$ & & & 8.40 & 1.95 & & & & & & & 0.2321 \\
\hline $\begin{array}{l}<0.2 \mu \text { U calc } c \\
W 27.3 \text { (Snow }\end{array}$ & donia, W & (ales) & 8.941 & 2.167 & & & & & & & 0.2424 \\
\hline $\begin{array}{l}<0.2 \mu \text { L AcAcid } \\
<0.2 \mu R\end{array}$ & ...-- & 1.28 & $\begin{array}{l}0.491 \\
19.0\end{array}$ & $\begin{array}{l}0.117 \\
3.50\end{array}$ & 0.0410 & 0.132 & 0.0926 & 0.0492 & 0.0489 & 0.00834 & $\begin{array}{l}0.2383 \\
0.1842\end{array}$ \\
\hline$<0.2 \mu$ U calc $\mathrm{c}$ & & & 19.49 & 3.617 & & & & & & & 0.1856 \\
\hline \multicolumn{12}{|l|}{ W 27.4} \\
\hline$<0.2 \mu$ L Ac Acid & 0.511 & 1.33 & 0.555 & 0.131 & 0.0405 & 0.162 & 0.110 & 0.0600 & 0.0491 & 0.00824 & 0.2360 \\
\hline$<0.2 \mu \mathrm{L} \mathrm{HCl}$ & & 23.2 & 9.02 & 1.51 & 0.265 & 1.08 & 0.509 & 0.178 & 0.115 & 0.0149 & 0.1674 \\
\hline$<0.2 \mu \mathrm{R}$ & & & 16.3 & 3.03 & & & & & & & 0.1859 \\
\hline$<0.2 \mu \mathrm{U}$ calc c & & & 25.88 & 4.671 & & & & & & & 0.1805 \\
\hline$<0.2 \mu \mathrm{L}$ Ac Acid & & & 0.700 & 0.167 & & & & & & & 0.2386 \\
\hline$<0.2 \mu R$ & & & 25.1 & 4.51 & & & & & & & 0.1797 \\
\hline$<0.2 \mu \mathrm{U}$ calc $\mathrm{c}$ & & & 25.80 & 4.677 & & & & & & & 0.1813 \\
\hline$<0.2 \mu U$ & & & 28.8 & 5.34 & & & & & & & 0.1854 \\
\hline Blank (pg) & 6.1 & 690 & 20 & 5.7 & 1.0 & 13 & 9.8 & 5.0 & 6.7 & 1.2 & \\
\hline
\end{tabular}

(a): $U$ = untreated sample; $L=$ leachate; $R=$ residue after leaching. (b): REE concentrations (ppm; error $\leq 1 \%)$ are corrected for blank contribution. (c): these concentrations are calculated relative to the sample weight prior to leaching; hence [L] + [R] $=[\mathrm{U}]$ in ppm. (d): these concentrations for ZB11U are measured. (e): Error of blank: $\leq 15 \%$.

\section{REE patterns}

In an effort to better understand the mineralogical controls on the rare earth distribution in shales, REE cuncentrations were determined for the leachates of samples W22.2 (Llanvirnian, anchizone), W27.3, and W27.4 (Llanvirnian, epizone). In the case of W22.2, whole-rock and residue patterns were determined as well. For comparison, new REE abun- 
Table 4. Sm-Nd and Rb-Sr results for samples W5-1 and W3c from Wales; results of adsorption experiment on W16.2; ICP concentration data on selected $<0.2 \mu \mathrm{m}$ aliquots of Welsh samples.

\begin{tabular}{|c|c|c|c|c|c|c|c|c|c|}
\hline \multicolumn{2}{|c|}{ W5-1 turbidite } & $\mathbf{R b}^{\mathbf{a}}$ & $\mathrm{Sr}^{\mathbf{a}}$ & ${ }^{87} \mathrm{Rb} /{ }^{86} \mathrm{Sr}$ & ${ }^{87} \mathrm{Sr} /{ }^{\beta 6} \mathrm{Sr}$ & $\mathrm{Sm}^{\mathrm{a}}$ & $\mathbf{N d}^{\mathbf{a}}$ & ${ }^{147} \mathrm{Sm} /{ }^{144} \mathrm{Nd}$ & ${ }^{143} \mathrm{Nd} / 144 \mathrm{Nd}$ \\
\hline \multicolumn{10}{|c|}{ host rock } \\
\hline $5-1 \mathrm{~A}$ & $u^{b}$ & 94.61 & 76.95 & 3.566 & $0.732515(11)$ & 1.244 & 4.643 & 0.16206 & $0.512198(11)$ \\
\hline 5-1 M & $\begin{array}{l}\mathrm{L} \\
\mathrm{R} \\
\mathrm{U} \text { calc }\end{array}$ & $\begin{array}{c}47.97 \\
77.37 \\
125.3\end{array}$ & $\begin{array}{c}69.67 \\
38.38 \\
108.1\end{array}$ & $\begin{array}{l}1.996 \\
5.846\end{array}$ & & & & & \\
\hline & $\mathrm{U}$ & 121.7 & 105.2 & 3.357 & & & & & \\
\hline \multicolumn{10}{|c|}{ apatite concretion } \\
\hline $5-1$ B & $\begin{array}{l}\mathrm{L} \\
\mathbf{R} \\
\mathrm{U} \text { calc }\end{array}$ & $\begin{array}{l}1.180 \\
16.42 \\
17.60\end{array}$ & $\begin{array}{c}125.7 \\
12.19 \\
137.9\end{array}$ & $\begin{array}{l}0.02718 \\
3.907\end{array}$ & $\begin{array}{l}0.710449(14) \\
0.736283(16)\end{array}$ & $\begin{array}{l}37.84 \\
0.2490 \\
38.09\end{array}$ & $\begin{array}{l}74.05 \\
0.7828 \\
74.83\end{array}$ & $\begin{array}{l}0.30896 \\
0.19247\end{array}$ & $0.512707(8)$ \\
\hline $5-1 \mathrm{C}$ & $\begin{array}{l}\mathbf{L} \\
\mathbf{R} \\
\text { U calc }\end{array}$ & $\begin{array}{l}0.7869 \\
13.08 \\
13.87\end{array}$ & $\begin{array}{c}125.2 \\
9.435 \\
134.6\end{array}$ & $\begin{array}{l}0.01819 \\
4.024\end{array}$ & $\begin{array}{l}0.710224(11) \\
0.738220(13)\end{array}$ & $\begin{array}{l}40.24 \\
0.2160 \\
40.46\end{array}$ & $\begin{array}{l}82.07 \\
0.6538 \\
82.72\end{array}$ & $\begin{array}{l}0.29645 \\
0.19992\end{array}$ & $0.512705(8)$ \\
\hline 5-1 D & $\begin{array}{l}\text { L Ac } \\
\text { L IN } \\
\text { L } 6 \mathrm{~N} \\
R \\
\text { U calc }\end{array}$ & $\begin{array}{c}0.2950 \\
0.3191 \\
0.1656 \\
15.80 \\
16.58\end{array}$ & $\begin{array}{c}13.92 \\
121.8 \\
11.75 \\
11.66 \\
159.1\end{array}$ & $\begin{array}{l}0.06128 \\
0.007581 \\
0.04078 \\
3.933\end{array}$ & $\begin{array}{l}0.711179(11) \\
0.710134(14) \\
0.710299(14) \\
0.735474(21)\end{array}$ & $\begin{array}{c}5.127 \\
40.78 \\
4.084 \\
0.1657 \\
50.16\end{array}$ & $\begin{array}{c}11.11 \\
81.86 \\
8.098 \\
0.5263 \\
101.6\end{array}$ & $\begin{array}{l}0.27903 \\
0.30119 \\
0.30492 \\
0.19051\end{array}$ & $\begin{array}{l}0.512568(7) \\
0.512680(9) \\
0.512710(10)\end{array}$ \\
\hline $5-1 \mathrm{~T}$ & $\begin{array}{l}\text { L1 rim } \\
\text { L4 ctr } \\
\text { L.5 rim }\end{array}$ & $\begin{array}{c}16.30 \\
2.074 \\
13.19\end{array}$ & $\begin{array}{c}71.65 \\
176.5 \\
39.49\end{array}$ & $\begin{array}{l}0.6586 \\
0.03401 \\
0.9671\end{array}$ & $\begin{array}{l}0.710587(18) \\
0.717297(68)\end{array}$ & & & & \\
\hline \multicolumn{10}{|c|}{ Bentonite W3c } \\
\hline & $\begin{array}{l}\text { L Ac } \\
\text { L } 1 N \\
\text { U }\end{array}$ & $\begin{array}{r}1.15 \\
199.5\end{array}$ & $\begin{array}{c}1.62 \\
363.5\end{array}$ & $\begin{array}{l}2.061 \\
1.589\end{array}$ & $\begin{array}{l}0.722062(40) \\
0.716986(20)\end{array}$ & $\begin{array}{l}0.00357 \\
0.6998 \\
10.86\end{array}$ & $\begin{array}{c}0.00866 \\
2.419 \\
58.67\end{array}$ & $\begin{array}{l}0.2497 \\
0.17485 \\
0.11189\end{array}$ & $\begin{array}{l}0.512335(12) \\
0.512087(4)\end{array}$ \\
\hline
\end{tabular}

W16.2 Leaching-adsorption experiment

\begin{tabular}{|c|c|c|c|c|c|c|}
\hline measured ratio & acetic acid & $\%$ adsorbed & hydrochloric acid & $\%$ adsorbed & natural ratio & spike ratio \\
\hline${ }^{150} \mathrm{Nd} / 144 \mathrm{Nd}$ & 0.24206 & $0.5-0.7$ & 0.23762 & $0.07-0.1$ & 0.23647 & 57.38 \\
\hline${ }^{142} \mathrm{Ce} / /^{140} \mathrm{Ce}$ & 0.12721 & $(0.3)$ & 0.12630 & $(0.15)$ & 0.1251 & 11.567 \\
\hline${ }^{153} \mathrm{Eu} /{ }^{151} \mathrm{Eu}$ & 1.1322 & $(0.5)$ & 1.1064 & $(0.08)$ & 1.0934 & 124.0 \\
\hline
\end{tabular}

ICP concentration data $c$

\begin{tabular}{|c|c|c|c|c|c|c|c|}
\hline & $2 \mathrm{a} 1 \mu \mathrm{LH}$ & $15.30 .2 \mu \mathrm{LH}$ & $16.20 .2 \mu \mathrm{LH}$ & $22.20 .2 \mu \mathrm{L} \mathrm{H}$ & $27.40 .2 \mu \mathrm{L} \mathrm{H}$ & $2 \mathrm{a} 1 \mu \mathrm{R} \mathrm{H}$ & $22.20 .2 \mu$ R H \\
\hline $\begin{array}{l}\mathrm{Si} \\
\mathrm{Al} \\
\mathrm{Fe} \\
\mathrm{Mg} \\
\mathrm{Ca} \\
\mathrm{Na} \\
\mathrm{K} \\
\mathrm{P}\end{array}$ & $\begin{array}{c}8.01 \\
12.0 \\
3.78 \\
1.79 \\
2.88 \\
12.7 \\
3.40 \\
3.70\end{array}$ & $\begin{array}{l}6.59 \\
9.90 \\
4.82 \\
0.882 \\
1.39 \\
7.94 \\
3.59 \\
2.60\end{array}$ & $\begin{array}{c}5.91 \\
5.27 \\
4.26 \\
1.26 \\
0.776 \\
14.9 \\
4.57 \\
3.00\end{array}$ & $\begin{array}{c}8.93 \\
5.98 \\
5.21 \\
1.51 \\
2.29 \\
18.1 \\
5.36 \\
3.29\end{array}$ & $\begin{array}{c}8.49 \\
11.2 \\
13.6 \\
2.18 \\
0.855 \\
3.36 \\
1.64 \\
4.71\end{array}$ & $\begin{array}{l}-. . \\
2.48 \\
0.647 \\
0.227 \\
0.0068 \\
0.032 \\
0.891 \\
0.194\end{array}$ & $\begin{array}{l}-. . \\
12.8 \\
2.89 \\
0.724 \\
0.026 \\
0.499 \\
3.59 \\
0.85\end{array}$ \\
\hline $\begin{array}{l}\mathrm{Fe} / \mathrm{Mg}_{\mathbf{g}} \\
\mathrm{K} / \mathrm{Al} \\
\mathrm{Ca} / \mathbf{P}\end{array}$ & $\begin{array}{l}2.11 \\
0.28 \\
0.78\end{array}$ & $\begin{array}{l}5.46 \\
0.36 \\
0.53\end{array}$ & $\begin{array}{l}3.38 \\
0.87 \\
0.26\end{array}$ & $\begin{array}{l}3.45 \\
0.90 \\
0.70\end{array}$ & $\begin{array}{l}6.24 \\
0.15 \\
0.18\end{array}$ & $\begin{array}{l}2.85 \\
0.36 \\
0.035\end{array}$ & $\begin{array}{l}3.99 \\
0.28 \\
0.031\end{array}$ \\
\hline
\end{tabular}

a: all concentrations are calculated relative to the sample weight prior to leaching, hence $[L]+[R]=[U]$ ppm. b: $U=$ untreated sample, $\mathrm{L}=$ leachate, $\mathrm{R}=$ residue after leaching, $\mathrm{U}$ calc $=$ calculated concentration from leachate and residue, $\mathrm{Ac}=$ acetic acid, $1 \mathrm{~N}=$ cold $1 \mathrm{~N} \mathrm{HCl}, 6 \mathrm{~N}=$ cold $6 \mathrm{~N} \mathrm{HCl}$. c: in $\mu \mathrm{g} / \mathrm{ml}$; dilution factor is1, except $27.4 \mathrm{~L}$ (DF =3) and the residues $(\mathrm{DF}=100)$. 


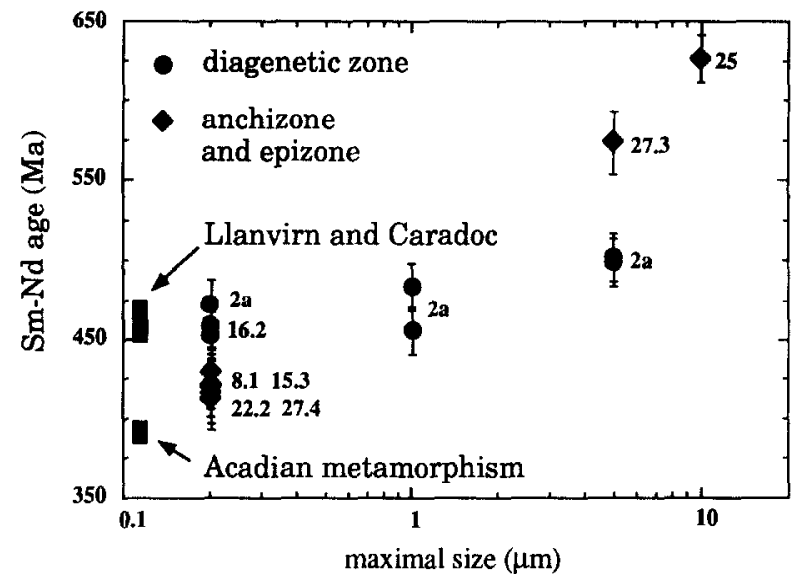

FIG . 4. Apparent Sm-Nd ages of Welsh rocks plotted against grain size. Sm-Nd ages are calculated from two-point leachate-residue pairs. The smallest size fractions yield ages that are bracketed by the time of deposition and the time of metamorphism.

dance data of a representative clay separate of a deeply buried Gulf Coast shale (OHR et al., 1991) are presented as well (Table 3).

Rather than normalizing leachate and residue data to a standard reference material such as the North American shale composite (NASC), actual REE concentrations of the corresponding bulk, whole-rock sample (WR) were used. On a chondrite-normalized plot (Fig. 7a), WR 22.2 is characterized by a LREE-enriched pattern, and relatively flat MREE and HREE, with a negative Eu anomaly of 0.70 . The normalizing values used are those for the Leedy chondrite (MASUDA et al., 1973), and the Eu anomaly is expressed as suggested by MCLENNAN (1991). The whole-rock pattern is typical of shale, and the absolute REE concentrations are consistent with average values for post-Archean shales (TAYLOR and MCLENNAN, 1985). Compared to NASC (GROMET et al., 1984), the HREEs of WR 22.2 are negatively fractionated with respect to the MREEs. This is not due to incomplete dissolution of residual accessory phases such as zircon, as dissolution in PFA vials (analysis 1) and dissolution using a Teflon bomb (analysis 2 ) yielded the same low concentrations of Dy through Lu relative to Gd (Table 3 ).

Compared to the whole rock, both the acetic acid and 1 $\mathrm{N} \mathrm{HCl}$ leachate of W22.2 $(<0.2 \mu \mathrm{m})$ are depleted in the LREEs and the HREEs (Fig. 7b). In a shale-normalized plot, both leachates display convex upward patterns that are centered around Gd (Fig. 7d). Similar patterns have been described for macroscopic biogenic apatite and apatite concretions in Paleozoic sediments (WRIGHT et al., 1987; GRANDJEAN et al., 1987; GRANDJEAN and ALbARÈD, 1989; MILODOWSKI and ZALASKIEWICZ, 1991). Plotted in the same manner, the residue of this sequential leaching procedure displays a roughly convex downward pattern, with the LREEs and HREEs enriched over the MREEs. The position and shape of the $\mathrm{HCl}$ leachate pattern is intermediate between that of the acetic acid leachate and the residue pattern. This is related either to the increased solubility of LREE-enriched phases in $\mathrm{HCl}$, or to the partial release of REEs from the phyllosilicates due to the acid attack. Finally, the presence of a positive $\mathrm{Ce}$ anomaly in the $\mathrm{HCl}$ leachate may be caused by leaching hydrous iron and manganese oxides; these are soluble in $\mathrm{HCl}$ and typically carry excess $\mathrm{Ce}$ in the form of oxidized $\mathrm{Ce}^{4+}$, but are insoluble in weakly dissociating acetic acid, and correspondingly produce no $\mathrm{Ce}$ anomaly in that leach.
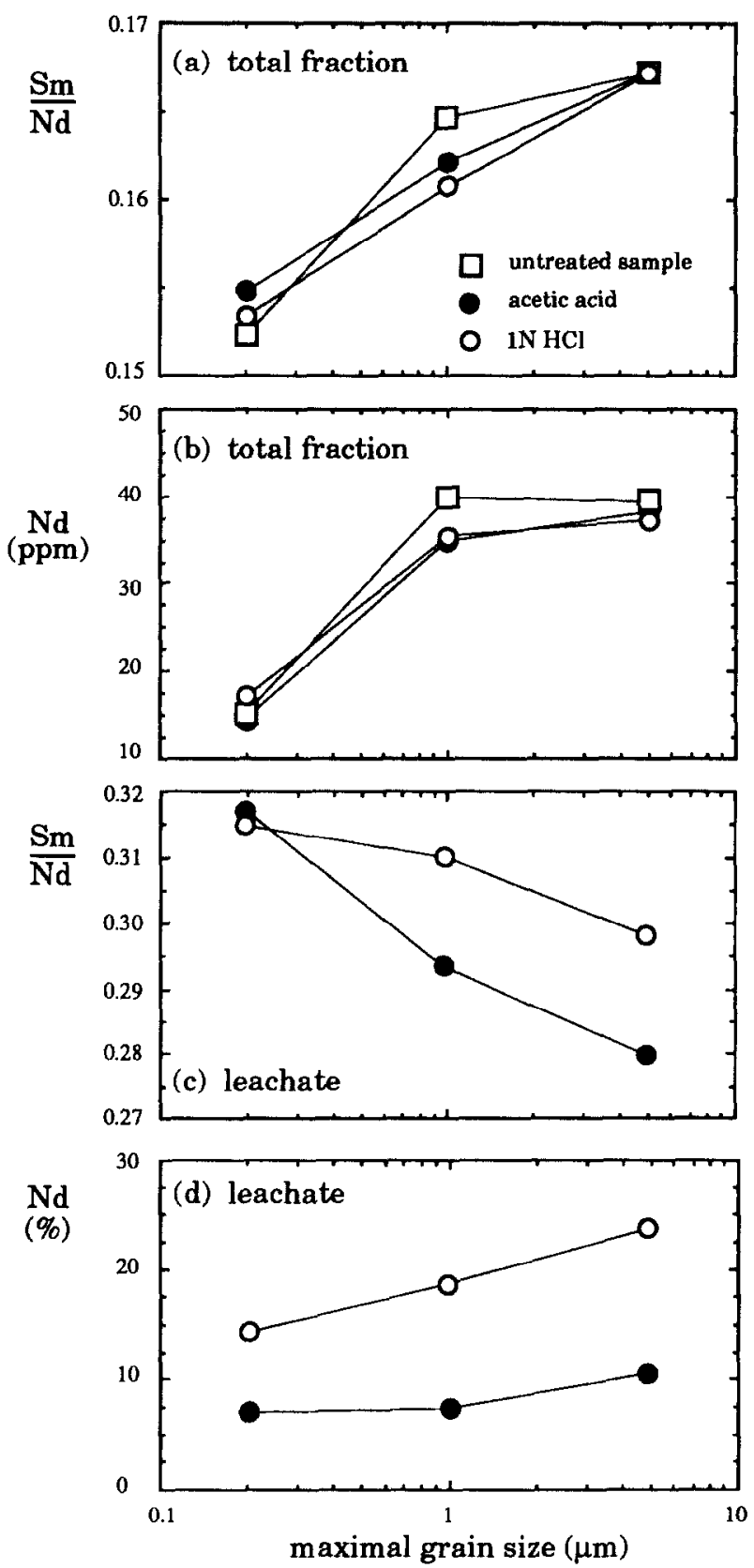

FIG. 5. Sm-Nd ratios and Nd abundances of sample W2a plotted against grain size; squares represent the measured total fraction, and the circles represent the reintegrated total fraction from acetic acid and $\mathrm{HCl}$ leaching procedures. (a) and (b) The lowest Sm-Nd ratios and $\mathrm{Nd}$ concentrations in the total fraction are associated with the smallest size fraction. (c) Leachates from the $<0.2 \mu \mathrm{m}$ fraction have the highest $\mathrm{Sm}-\mathrm{Nd}$ ratio and (d) contain the least Nd relative to the total fraction. 


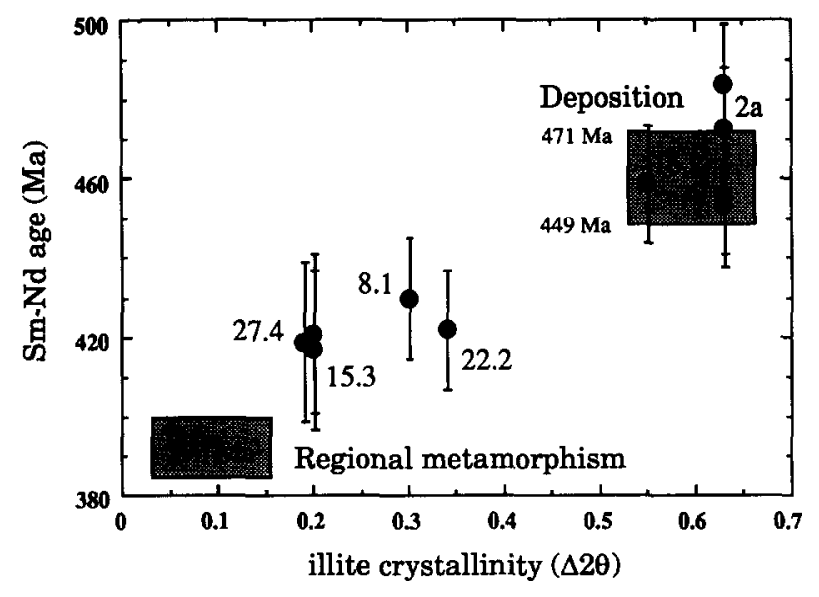

FIG. 6. Apparent Sm-Nd ages of Welsh rocks plotted against illite crystallinity. Sm-Nd ages are calculated from two-point leachate-residue pairs. Diagenetic samples $\left(\Delta 2 \theta>0.42^{\circ}\right)$ yield depositional ages; anchizonal and epizonal samples $\left(\Delta 2 \theta<0.42^{\circ}\right)$ yield intermediate ages toward the time of metamorphism.

The results for the higher grade samples W27.3 $(<5 \mu \mathrm{m})$ and W27.4 $(<0.2 \mu \mathrm{m})$ are distinct from those for W22.2. Plotted normalized to chondritc, all leachates are cnriched in LREEs, and the $\mathrm{HCl}$ leachate of W27.4 actually has a higher Sm-Nd ratio than the corresponding residue (Fig. 7c). The shale-normalized patterns of the acetic acid leachates are nearly flat with positive excursions for $\mathrm{Eu}$ and $\mathrm{Gd}$, reminiscent of the convex shapes of the W22.2. The $\mathrm{HCl}$ leachate has a discontinuous shale-normalized pattern with a slight LREE enrichment and a strong HREE depletion (Fig. 7f).

A REE fractionation similar to that observed in the Welsh samples has been reported from Texas Gulf Coast shales (AWWILLER and MACK, 1991; OHR et al., 1991). New REE data on a Paleocene shale from a previously studied deep well (OHR et al., 1991) are presented here to compare the REE distribution in Gulf Coast rocks that are solely affected by burial metamorphism with that of the regionally metamorphosed Welsh pelites. Chondrite-normalized and wholerock normalized patterns for ZB11 are overall very similar to those for W22.2 (Fig. 7a,b and d,e). The residue pattern in Fig. 7d is strictly symmetrical around Gd, with the LREEs and HREEs being equally enriched.

The acetic acid leachates of all samples have REE contents that are overall lower than those of the $\mathrm{HCl}$ leachates but have higher Sm-Nd ratios. REE concentrations in the acetic acid leachate relative to the $\mathrm{HCl}$ leachate are lowest for ZB1 1 (approximately 10\%), and highest for W22.2 (20 to 64\%). These relations are identical to those of the Welsh samples shown in Fig. 5c,d. The residues contain approximately $90 \%$ of the LREEs, $42-70 \%$ of the MREEs, and $80-95 \%$ of the HREEs (Table 3).

\section{Samples from New York}

\section{Onondaga Group (Middle Devonian)}

Three leaching experiments were performed on a $<0.2 \mu \mathrm{m}$ separate of one selected sample, using $10 \%$ acetic acid, cold
$0.1 \mathrm{~N} \mathrm{HCl}$, and cold $1 \mathrm{~N} \mathrm{HCl}$. All Rb-Sr data are listed in Table 5. Rubidium and strontium abundances were calculated relative to the sample weight prior to leaching. Thus, the sums of $R b_{(L)}+R b_{(R)}$, and $S r_{(L)}+S r_{(R)}$ are equal to the concentration of $\mathrm{Rb}$ and $\mathrm{Sr}$ in the untreated sample. To compute element abundances in such a way is helpful in representing the proportions of each element in leachate and residue, respectively. The three leachates define a line with a slope corresponding to an age of $367 \pm 4 \mathrm{Ma}$ (MSWD $=2.76$ ), whereas the complementary residue isochron corresponds to $404 \pm 8 \mathrm{Ma}$ (MSWD $=0.47$; Fig. 8a). Individual $\mathrm{L}-\mathrm{R}$ ages range from $423 \pm 5 \mathrm{Ma}(0.1 \mathrm{~N} \mathrm{HCl})$ to $420 \pm 5$ $\mathrm{Ma}(1 \mathrm{~N} \mathrm{HCl}$ ) to $410 \pm 4 \mathrm{Ma}$ (acetic acid). Although all L$R$ pairs are approximately collinear, regressing a total leachate-residue isochron is equivocal because the data points are dependent on one another. However, a six-point regression assuming scatter in the initial $\mathrm{Sr}$ isotopic ratio for all three pairs yields an age of $417 \pm 8 \mathrm{Ma}$. The reintegrated total concentrations are quite variable and possibly related to the low initial weight and hence heterogeneity of the bulk separate. Sm-Nd data were obtained from two independent experiments. Set 1 includes analyses for the leachates only; set 2 includes both leachate and residue data. In Fig. 8b, the slope of the leachate regression corresponds to an age of 392 $\pm 5 \mathrm{Ma}(\mathrm{MSWD}=0.01$ ) for set 1 , and $377 \pm 23 \mathrm{Ma}$ for set 2 (not including the $1 \mathrm{~N} \mathrm{HCl}$ leachate, which is similar to that from set 1 ). The individual $L-R$ tie lines of set 2 range from $390 \pm 18 \mathrm{Ma}$ (acetic acid) to $425 \pm 26 \mathrm{Ma}(0.1 \mathrm{~N} \mathrm{HCl})$ to $471 \pm 37 \mathrm{Ma}(1 \mathrm{~N} \mathrm{HCl})$. The combined leachate and residue isochron age of set 2 is $402 \pm 13 \mathrm{Ma}$ (MSWD $=1.63$ ), with the same limitations regarding the dependence of the data as above.

The "leachate-only" Rb-Sr and Sm-Nd isochrons define stratigraphic ages or ages that are slightly younger than the time of deposition ( $390 \mathrm{Ma}$ ). Ages that include residue data are either concordant with deposition or somewhat older. It is therefore possible that the separates are not quite finegrained enough, and that they include a small proportion of detrital, clastic material. The presence of quartz in the $<0.2$ $\mu \mathrm{m}$ separate as revealed by powder X-ray diffraction (chlorite $>$ illite $>$ quartz) is certainly indicative in this respect. The close agreement of $\mathrm{Sm}-\mathrm{Nd}$ ages with $\mathrm{Rb}-\mathrm{Sr}$ ages (e.g., 390 $\pm 18 \mathrm{Ma}$ vs. $410 \pm 4 \mathrm{Ma}$ for the acetic acid procedure) is also noteworthy. We suspect that the relative abundance of chlorite vs. poorly crystalline illite is important, in that $\mathbf{R b}$ $\mathrm{Sr}$ ages appear to generally correspond well with $\mathrm{Sm}-\mathrm{Nd}$ ages in chlorite-rich assemblages. This is also documented by similarly concordant $\mathrm{Rb}-\mathrm{Sr}$ and $\mathrm{Sm}-\mathrm{Nd}$ results for chlorite-rich rocks from Wales. In contrast, the results of illite-rich Welsh samples suggest that radiogenic $\mathrm{Sr}$ and $\mathrm{Rb}$ seem to have "leaked" in unpredictable proportions into the leachates, causing the Rb-Sr ages to be scattered over a large time interval (Table 2; Fig. 3b).

\section{Trenton Limestone and Utica Formation (Middle Ordovician)}

The whole-rock chemistry of shales of the Utica Formation displays a regular decrease in $\mathrm{Ca}-\mathrm{Mg}$ ratios from the bottom 

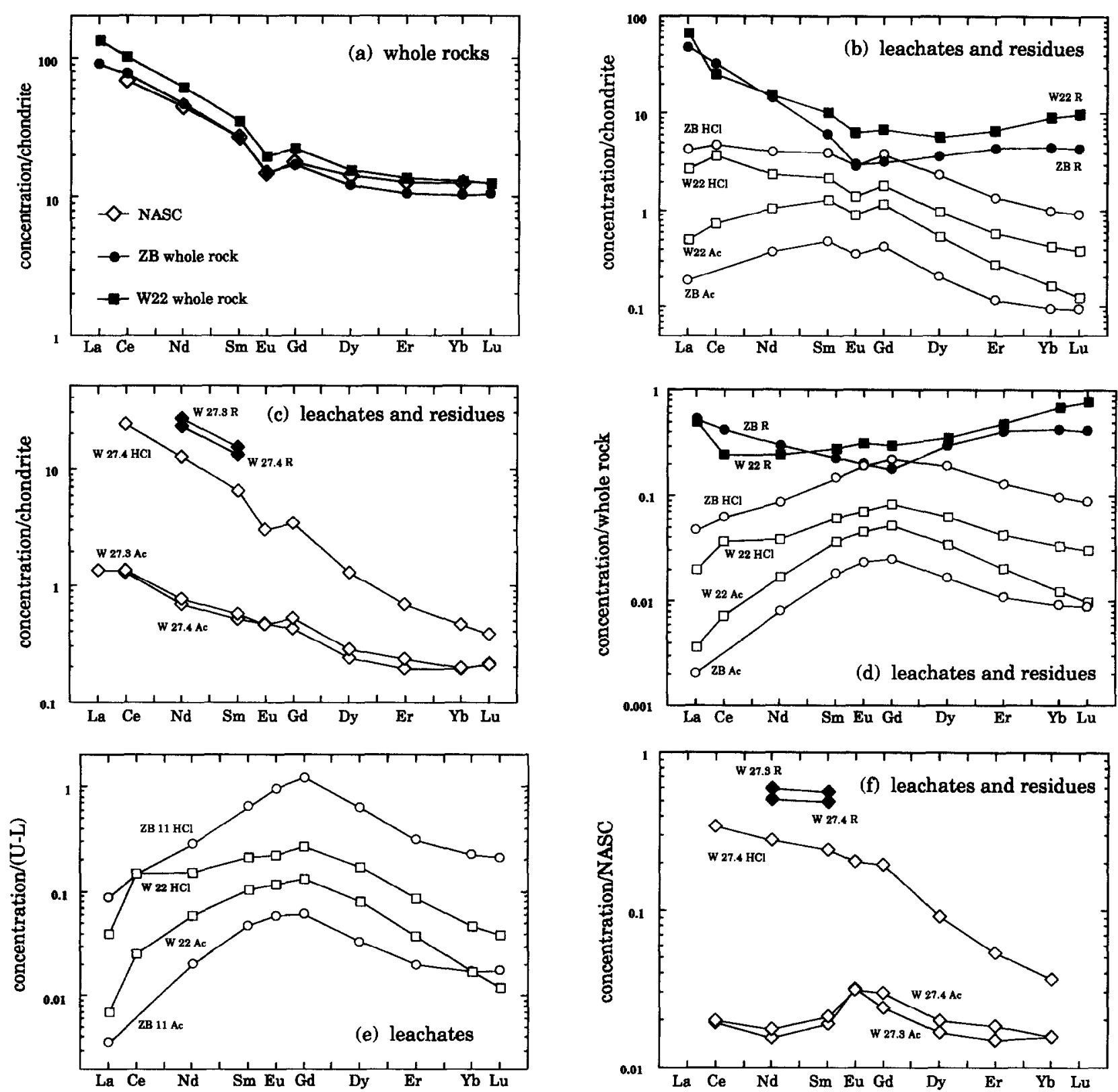

FIG. 7. REE abundance patterns of leachate, residues, and whole-rock fractions; (a) through (c) are chondrite normalized, (d) through ( $f$ ) are normalized to whole-rock and residue concentrations. (a) Whole rocks W22.2 and ZB11 are overall similar to the North American Shale Composite (NASC). (b) Leachates (open symbols) of the $<0.2$ $\mu \mathrm{m}$ fraction of W22.2 and ZB11 are MREE enriched, whereas residues (filled symbols) are MREE depleted. (c) Leachate patterns of the $<0.2 \mu \mathrm{m}$ fraction of W27.3 and W27.4 (epizone) are LREE enriched, with the HCl leachate having a greater ${ }^{147} \mathrm{Sm} /{ }^{144} \mathrm{Nd}$ than the corresponding residue. (d) Shale-normalized, convex-upward patterns of the leachates of W22.2 and ZB1I are typical for diagenetic apatite. Residues have a complementary convex-downward pattern due to primary apatite REE fractionation. (e) Leachate patterns most closely resemble REE "partition coefficients" of apatite when normalized to residues. (f) NASC normalized leachate patterns of W27.3 and W27.4 are more ambiguous; only the acetic acid leachates are slightly MREE enriched.

to the top of the Utica Formation (J. W. Delano, pers. commun.), mirroring a transition from calcite-rich to dolomiterich cements. This trend in bulk rock composition is correlated with ${ }^{87} \mathrm{Sr} /{ }^{86} \mathrm{Sr}$ ratios of the whole-rock leachates (no time correction is necessary as ${ }^{87} \mathrm{Rb} /{ }^{86} \mathrm{Sr}$ is less than 0.01 ; Table 6). The most calcite-rich shales display leachate $\mathrm{Sr}$ ratios of $0.7081-0.7082$. As the sediment becomes more dolomite-rich, the ${ }^{87} \mathrm{Sr} /{ }^{86} \mathrm{Sr}$ ratios of the leachates increase to 0.7093 (Fig. 9a). Occasional carbonate-rich turbidites that are interlayered with shales of the Utica Formation fit this trend neatly: a calcite-turbidite from the Lower Utica Formation, and a dolomite-turbidite from the Upper Utica For- 
Table 5. Rb-Sr and Sm-Nd results for samples from New York

\begin{tabular}{|c|c|c|c|c|c|c|}
\hline \multicolumn{2}{|c|}{ Onondaga Gp. siltstone } & \multirow{2}{*}{$\begin{array}{r}\mathrm{Rb}^{\mathrm{b}} \\
3.03 \\
85.94 \\
88.97\end{array}$} & \multirow{2}{*}{$\begin{array}{r}\mathrm{Sr} b \\
8.46 \\
37.82 \\
46.28\end{array}$} & \multirow{2}{*}{$\begin{array}{c}8^{87} \mathrm{Rb} / 86 \mathrm{Sr} \\
1.035 \\
6.602\end{array}$} & \multirow{2}{*}{$\begin{array}{l}{ }^{87} \mathrm{Sr} / 86 \mathrm{Sr} \\
0.716564(15) \\
0.750079(20)\end{array}$} & \\
\hline $0.1 \mathrm{~N} \mathrm{HCl}$ & $\begin{array}{l}\mathrm{L} \\
\mathrm{R} \\
\mathrm{U}\end{array}$ & & & & & \\
\hline $1 \mathrm{~N} \mathrm{HCl}$ & $\begin{array}{l}\mathbf{L} \\
\mathbf{R} \\
\mathbf{U}\end{array}$ & $\begin{array}{c}4.43 \\
106.7 \\
111.1\end{array}$ & $\begin{array}{r}8.74 \\
32.68 \\
41.42\end{array}$ & $\begin{array}{l}1.469 \\
9.497\end{array}$ & $\begin{array}{l}0.718743(10) \\
0.766815(20)\end{array}$ & \\
\hline \multirow[t]{2}{*}{ Acetic acid } & $\begin{array}{l}\mathbf{L} \\
\mathbf{R} \\
\mathbf{U}\end{array}$ & $\begin{array}{c}0.556 \\
104.8 \\
105.4\end{array}$ & $\begin{array}{r}7.00 \\
28.85 \\
35.85\end{array}$ & $\begin{array}{c}0.2299 \\
10.57\end{array}$ & $\begin{array}{l}0.712340(14) \\
0.772704(25)\end{array}$ & \\
\hline & & $\mathrm{Sm}$ & Nd & ${ }^{147} \mathrm{Sm} / 144 \mathrm{Nd}$ & ${ }^{143} \mathrm{Nd} / 144 \mathrm{Nd}$ & $\varepsilon(\mathrm{Nd})^{\mathrm{c}}$ \\
\hline $0.1 \mathrm{~N} \mathrm{HCl}$ & $\begin{array}{l}\text { L1 } \\
\text { L2 } \\
\text { R2 } \\
\text { U2 }\end{array}$ & $\begin{array}{l}1.065 \\
3.561 \\
4.626\end{array}$ & $\begin{array}{l}4.170 \\
27.28 \\
31.45\end{array}$ & $\begin{array}{l}0.16962 \\
0.154436 \\
0.0789200\end{array}$ & $\begin{array}{l}0.512159(10) \\
0.512094(8) \\
0.511884(10)\end{array}$ & $\begin{array}{r}-9.3 \\
-10.6 \\
-14.7\end{array}$ \\
\hline IN HCl & $\begin{array}{l}\text { L1 } \\
\text { L2 } \\
\text { R2 } \\
\text { U2 }\end{array}$ & $\begin{array}{l}1.116 \\
2.464 \\
3.580\end{array}$ & $\begin{array}{l}4.795 \\
19.06 \\
23.86\end{array}$ & $\begin{array}{l}0.13981 \\
0.140704 \\
0.0781600\end{array}$ & $\begin{array}{l}0.512083(10) \\
0.512082(12) \\
0.511889(9)\end{array}$ & $\begin{array}{l}-10.8 \\
-10.9 \\
-14.6\end{array}$ \\
\hline Acetic acid & $\begin{array}{l}\mathrm{L} 1 \\
\mathrm{~L} 2 \\
\mathrm{R} 2 \\
\mathrm{U} 2\end{array}$ & $\begin{array}{l}0.4327 \\
2.737 \\
3.170\end{array}$ & $\begin{array}{l}1.291 \\
19.63 \\
20.92\end{array}$ & $\begin{array}{l}0.18608 \\
0.202638 \\
0.0842861\end{array}$ & $\begin{array}{l}0.512202(15) \\
0.512213(11) \\
0.511911(9)\end{array}$ & $\begin{array}{r}-8.5 \\
-8.3 \\
-14.2\end{array}$ \\
\hline \multicolumn{7}{|c|}{ Utica Formation } \\
\hline $88-044$ & $\begin{array}{l}\text { L } \\
\text { R } \\
\text { U }\end{array}$ & $\begin{array}{l}3.757 \\
1.759 \\
5.516\end{array}$ & $\begin{array}{l}8.925 \\
13.76 \\
22.69\end{array}$ & $\begin{array}{l}0.25447 \\
0.077253\end{array}$ & $\begin{array}{l}0.512284(10) \\
0.511827(10)\end{array}$ & $\begin{array}{r}-6.9 \\
-15.8\end{array}$ \\
\hline $88-091$ & $\begin{array}{l}\mathbf{L} \\
\mathbf{R} \\
\mathbf{U}\end{array}$ & $\begin{array}{l}4.086 \\
0.9580 \\
5.044\end{array}$ & $\begin{array}{l}13.64 \\
10.23 \\
23.87\end{array}$ & $\begin{array}{l}0.18104 \\
0.056581\end{array}$ & $\begin{array}{l}0.512068(10) \\
0.511807(10)\end{array}$ & $\begin{array}{l}-11.1 \\
-16.2\end{array}$ \\
\hline
\end{tabular}

a: $L, R$, and $U$ denote leachate, residue, and untreated sample, respectively; $b$ : all concentrations are calculated relative to the sample weight before leaching; hence [L] + [R] $=[U]$ in ppm. All concentrations for $U$ are calculated. c: relative to present-day ${ }^{142} \mathrm{Nd}^{14} \mathrm{Nd}$ $($ CHUR $)=0.612638$.

mation plot as endmembers of this trend. The ${ }^{87} \mathrm{Sr} /{ }^{86} \mathrm{Sr}$ ratio of 0.70804 from the only Trenton Limestone sample measured is indistinguishable from that of Middle Ordovician seawater (BURKE et al., 1982). The wide range of whole-rock leachate ${ }^{147} \mathrm{Sm} /{ }^{144} \mathrm{Nd}$ ratios is also correlated with decreasing whole-rock Ca-Mg ratios (Fig. 9b). Measured ${ }^{147} \mathrm{Sm} /{ }^{144} \mathrm{Nd}$ ratios range between 0.109 and 0.296 , and with their corresponding neodymium isotopic composition result in an isochron age of $458 \pm 25 \mathrm{Ma}$ (MSWD $=4.56$; Fig. 9c). The initial isotopic ratio of 0.51152 at $458 \mathrm{Ma}$ is equal to an $\epsilon_{(\mathrm{Nd})}$ value of -10.2 . Most Bean Hill samples plot above this line, as is the case with the two whole-rock residues that were analyzed. Data for the Trenton Limestone and two other samples from the base of the Utica Formation plot well below the isochron and define a much lower depositional $\epsilon_{(\mathrm{Nd})}$ value of about -18 , similar to values of seawater obtained by KETO and JACOBSON (1987).

This second suite of Appalachian foreland sediments was studied to further explore the usefulness of acquiring Sm-Nd ages of leachates only. In an earlier study of Texas Gulf Coast shales (OHR et al., 1991) we had observed that leachate neodymium isotopic compositions were in apparent isotopic equilibrium following diagenesis, regardless of the grain size of their respective bulk samples. At the time, we suggested that in certain cases it may be sufficient to analyze the soluble components of shales, given that a suitable range of $\mathrm{Sm}-\mathrm{Nd}$ ratios had developed. Results from the Utica Formation indeed indicate that leaching of powdered bulk shale samples can produce a leachate $\mathrm{Sm}-\mathrm{Nd}$ isochron age that corresponds to the time of deposition or early diagenesis, as the leachate compositions are correlated with the extent of diagenetic alteration of carbonate cements. This observation is consistent with and implicd by our data from Tertiary Gulf Coast shales (OHR et al., 1991). However, the ease and relative crudeness of this method is surprising and certainly merits further testing. Furthermore, the contrast in initial neodymium isotopic ratios between the westernmost samples from Harter Hill $\left(\epsilon_{\mathrm{fd})}=-18\right)$ and the Utica carbonate cements to the east $\left(\epsilon_{(\mathrm{Nd})}=-10.2\right)$ is consistent with the different regional geologic setting of the continental margin basin during the Taconic orogeny. To the west, the Trenton Limestone and the distal portion of the Utica Formation developed on the stable platform, and hence tapped a less radiogenic, cratonic $\mathrm{Nd}$ source. At the same time, the eastern part of the flysch basin subsided as the North American margin collided with the Taconic island arc, and consequently inherited a more ra- 

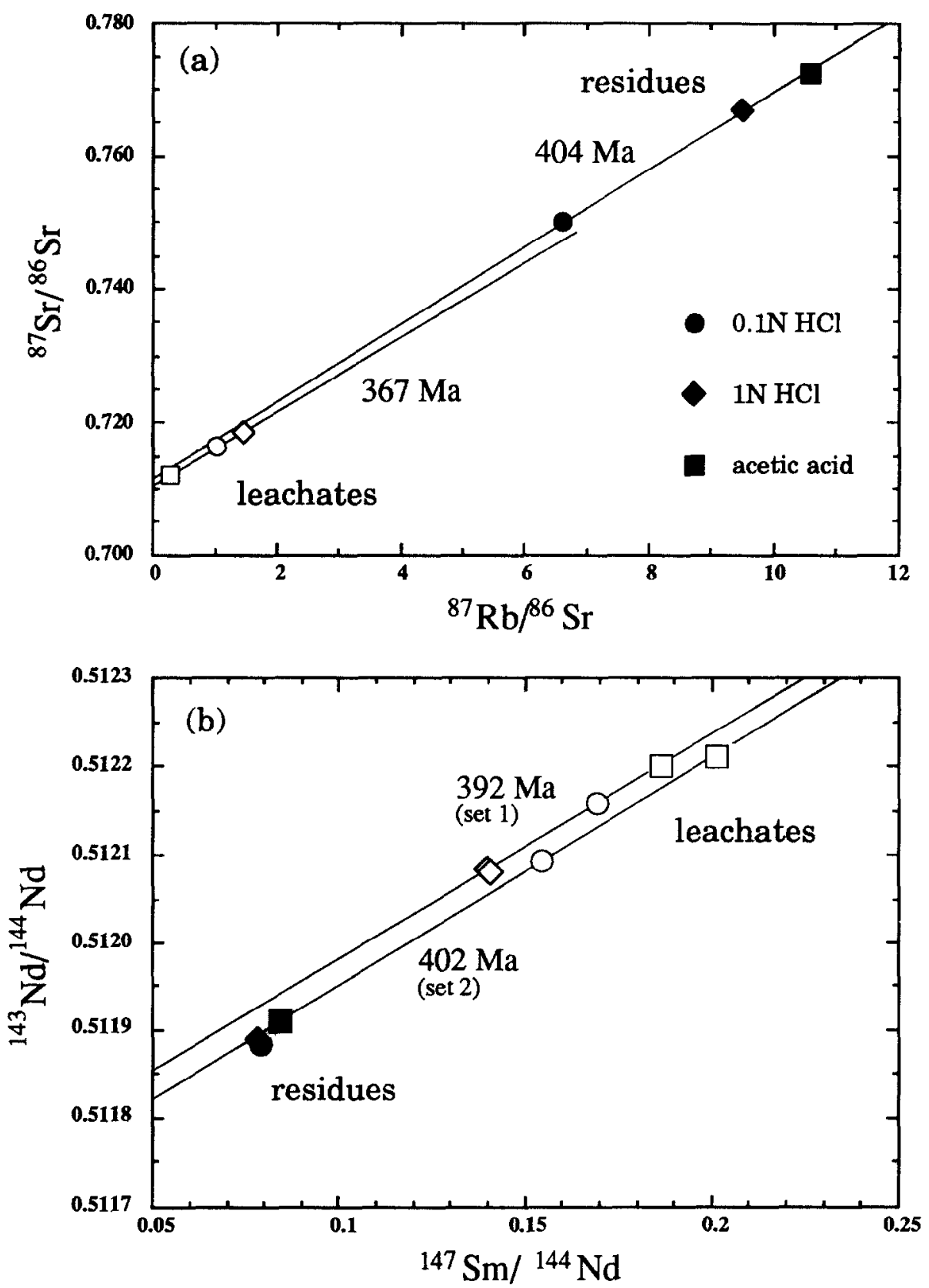

FIG. 8. Rb-Sr and Sm-Nd results of three leaching experiments using the $<0.2 \mu \mathrm{m}$ fraction of the Lower Devonian ( $390 \mathrm{Ma}$ ) siltstone sample (Onondaga Gp., New York). (a) ${ }^{87} \mathrm{Rb} /{ }^{86} \mathrm{Sr}$ vs. ${ }^{87} \mathrm{Sr} /{ }^{86} \mathrm{Sr}$ plot; leachate and residue isochron ages are $367 \pm 4 \mathrm{Ma}$ and $404 \pm 8 \mathrm{Ma}$, respectively. Two-point leachate-residue (L-R) ages range from 410 to $423 \mathrm{Ma}$. (b) ${ }^{147} \mathrm{Sm} /{ }^{144} \mathrm{Nd}$ vs. ${ }^{143} \mathrm{Nd} /{ }^{144} \mathrm{Nd}$ plot; combined leachate and residue ages are $392 \pm 5$ and $402 \pm 13 \mathrm{Ma}$, and twopoint L-R ages range from 390 to $471 \mathrm{Ma}$. Strontium and neodymium isotopic systematics are apparently unaffected by late Paleozoic diagenetic episodes related to remagnetization of the subjacent Onondaga Limestone.

diogenic neodymium isotopic signature from the converging active volcanic margin to the east. The presence of radiogenic volcanic detritus is also indicated in the younger than depositional L-R ages for two whole-rock samples (dashed lines in Fig. 9c). It seems that the arrival of juvenile, volcanic material from the Taconic island arc into the flysch basin is not just limited to the occurrence of numerous, stratigraphically well-defined bentonite layers; it is also expressed in form of a neodymium isotopic gradient in the main body of the turbiditic flysch sediments.
In summary, combined $\mathrm{Rb}-\mathrm{Sr}$ and $\mathrm{Sm}-\mathrm{Nd}$ evidence from clastic horizons overlying the Trenton and Onondaga Limestones indicate that presently coexisting phases have not been reset isotopically since early diagenesis. Furthermore, early diagenetic carbonate cements in shales may be used to constrain a depositional age. Finally, postulated diagenetic episodes related to Alleghenian remagnetization were either confined to the carbonate rocks, or, if the adjacent shale and siltstone units were involved, their $\mathrm{Rb}-\mathrm{Sr}$ and $\mathrm{Sm}-\mathrm{Nd}$ systems were not disturbed. 
Table 6. Sr and Nd isotopic results of bulk rock leachates from the Middle Ordovician, New York (Utica and Schenectady Fm., Trenton Lst.)

\begin{tabular}{|c|c|c|c|c|c|}
\hline Canajoharie & $\mathrm{Ca} / \mathrm{Mga}^{\mathrm{a}}$ & ${ }^{87} \mathrm{Sr} / 86 \mathrm{Sr}$ & ${ }^{143} \mathrm{Nd} /{ }^{144} \mathrm{Nd}^{\mathrm{b}}$ & ${ }^{147} \mathrm{Sm} /{ }^{144} \mathrm{Nd}$ & E(Na) \\
\hline 85-009 (Utica) & 28.9 & $0.708219(16)$ & $0.511880(11)$ & 0.11842 & -14.8 \\
\hline 87-116 (Utica) & 15.0 & $0.708376(14)$ & $0.512024(10)$ & 0.1428 & -12.0 \\
\hline 87-123 (Utica) I & 19.9 & $0.708451(17)$ & & & \\
\hline 87-123 (Utica) II & & $0.708516(18)$ & & & \\
\hline 88-044 (dol. turb.) I & 2.43 & $0.709211(13)$ & $0.512284(10)$ & 0.25447 & -6.9 \\
\hline 88-044 (dol. turb.) II & & & $0.512325(12)$ & 0.2722 & -6.1 \\
\hline 87-127 (Schenectady) & 1.25 & $0.711905(17)$ & $0.512261(9)$ & 0.2441 & -7.3 \\
\hline \multicolumn{6}{|l|}{ Bean Hill } \\
\hline 88-060 (Utica) & 16.5 & $0.708280(18)$ & $0.512052(18)$ & 0.1531 & -11.4 \\
\hline 88-063 (Utica) I & 24.2 & $0.708099(24)$ & $0.512049(16)$ & 0.1443 & -11.5 \\
\hline 88-063 (Utica) II & & $0.708125(17)$ & & & \\
\hline 88-088 (Utica) & 5.89 & $0.709305(15)$ & $0.512132(10)$ & 0.2224 & -9.9 \\
\hline 88-089 (Utica) I & 5.53 & $0.709039(12)$ & $0.512139(13)$ & 0.21182 & -10.0 \\
\hline 88-089 (Utica) II & & & $0.512123(22)$ & 0.2121 & -9.7 \\
\hline 88-091 (Utica) I & 9.94 & $0.708693(14)$ & $0.512068(10)$ & 0.18104 & -11.1 \\
\hline 88-091 (Utica) II & & & $0.512047(16)$ & 0.1813 & -11.5 \\
\hline 88-094 (Utica) I & 10.2 & $0.708486(14)$ & $0.512044(16)$ & 0.1581 & -11.5 \\
\hline 88-094 (Utica) II & & $0.708478(14)$ & & & \\
\hline $88-100$ (Schnenctady) & 1.87 & $0.711849(13)$ & $0.512425(12)$ & 0.2962 & -4.2 \\
\hline \multicolumn{6}{|l|}{ Harter Hill } \\
\hline $88-106$ (Trenton) & 75.7 & $0.708043(15)$ & $0.511494(10)$ & 0.11530 & -22.3 \\
\hline 88-109 (Utica) & 10.3 & $0.708305(14)$ & $0.511533(7)$ & 0.1272 & -21.6 \\
\hline 88-110 (cc. turb.) & 64.1 & $0.708093(15)$ & $0.511481(6)$ & 0.1091 & -22.6 \\
\hline
\end{tabular}

a: $\mathrm{Ca} / \mathrm{Mg}\left(w t\right.$. \%) of whole rock; b: bold print indicates ${ }^{143} \mathrm{Nd} /{ }^{144} \mathrm{Nd}$ ratio is measured on unspiked aliquot:; c: relative to present-day ${ }^{143} \mathrm{Nd}^{144} \mathrm{Nd}$ (CHUR) $=0.512638$.

\section{DISCUSSION}

\section{Accessory Phases and REE Distribution in Pelites from Wales}

In order to evaluate the character and extent of REE fractionation within individual components of the sediment, REE abundances of the $<0.2 \mu \mathrm{m}$ leachates and residues were normalized to (1) the whole-rock shale REE content (Fig. 7d) and (2) the complementary sample fraction(s) (Fig. 7e). In the case of a one-step leach, the leachate is normalized to the residue, and in the case of a sequential leach, leachate 1 is normalized to residue + leachate 2 . The REE patterns of sediments are usually presented normalized to a bulk shale reference. This is useful when comparing the overall REE fractionation in the sediment or its constituent components with an average upper crustal source. However, to evaluate the REE partitioning between phases within the sediment, it is appropriate to normalize one phase to another, or in this case, by normalizing leachate to residue. Only then do the resulting REE patterns most closely represent patterns of partition coefficients of the components that contribute to the leachates. Due to the regular decrease of ionic radius from the LREEs to the HREEs, accessory phases generally have distinctive patterns, and the dominant phase(s) that has been partitioned into the leachates may be identified. On the other hand, the absence of any regular REE pattern can be used to argue that the composition of the leachates is not, or only in a diffuse manner, caused by selective phase solubility.

As shown in Fig. 2, euhedral apatite is finely dispersed in the $<0.2 \mu \mathrm{m}$ separates, and the combined textural and chemical evidence presented here points decisively toward dissolved apatite as the main constituent of the leachate REE budget. Thus, the observed patterns may be explained as an expression of phase-controlled fractionation during early diagenesis. The arguments in favor of this interpretation can be summarized as follows: (1) Small, euhedral crystals of apatite are present in both the separates (TEM observation) and in thin section as documented by BSE imaging. (2) The leachates contain significant amounts of $\mathrm{Ca}$ and $\mathrm{P}$ (Table 4). (3) Paleozoic diagenetic apatite and apatite concretions display the same convex shale-normalized REE pattern (MILODOwSKI and ZALASKIEWICZ, 1991). (4) Between 25\% (Wales) and 55\% (Texas Gulf Coast) of the total MREEs reside in the leachate, and if actual dissolved sample weights are used (instead of the pre-leaching weight, as in Tables 2 to 4 ), the actual REE concentrations in the leached component can be as high as several hundred times chondritic abundances, which is typical of diagenetic apatite. (5) Neodymium isotopic data for macroscopic apatite from phosphate concretions in sample W5 (Lower Silurian, anchizone) from Wales plot just above the extension of the Ordovician $460 \mathrm{Ma}$ reference line through all leachates (Fig. 3a). The offset in ${ }^{143} \mathrm{Nd} /{ }^{144} \mathrm{Nd}$ is on the order of 50-70 ppm, which is consistent with the expected isotopic evolution of $\mathrm{Nd}$ from the mid-Ordovician to the early Silurian. These phosphate concretions also display a REE pattern identical to that of the leachate patterns (MILODOWSKI and ZALASKIEWICZ, 1991). (6) The Sr-Nd ratios of the leachates are about 1.5 , which is identical to the Sr$\mathrm{Nd}$ ratio of the apatite concretions mentioned above. 

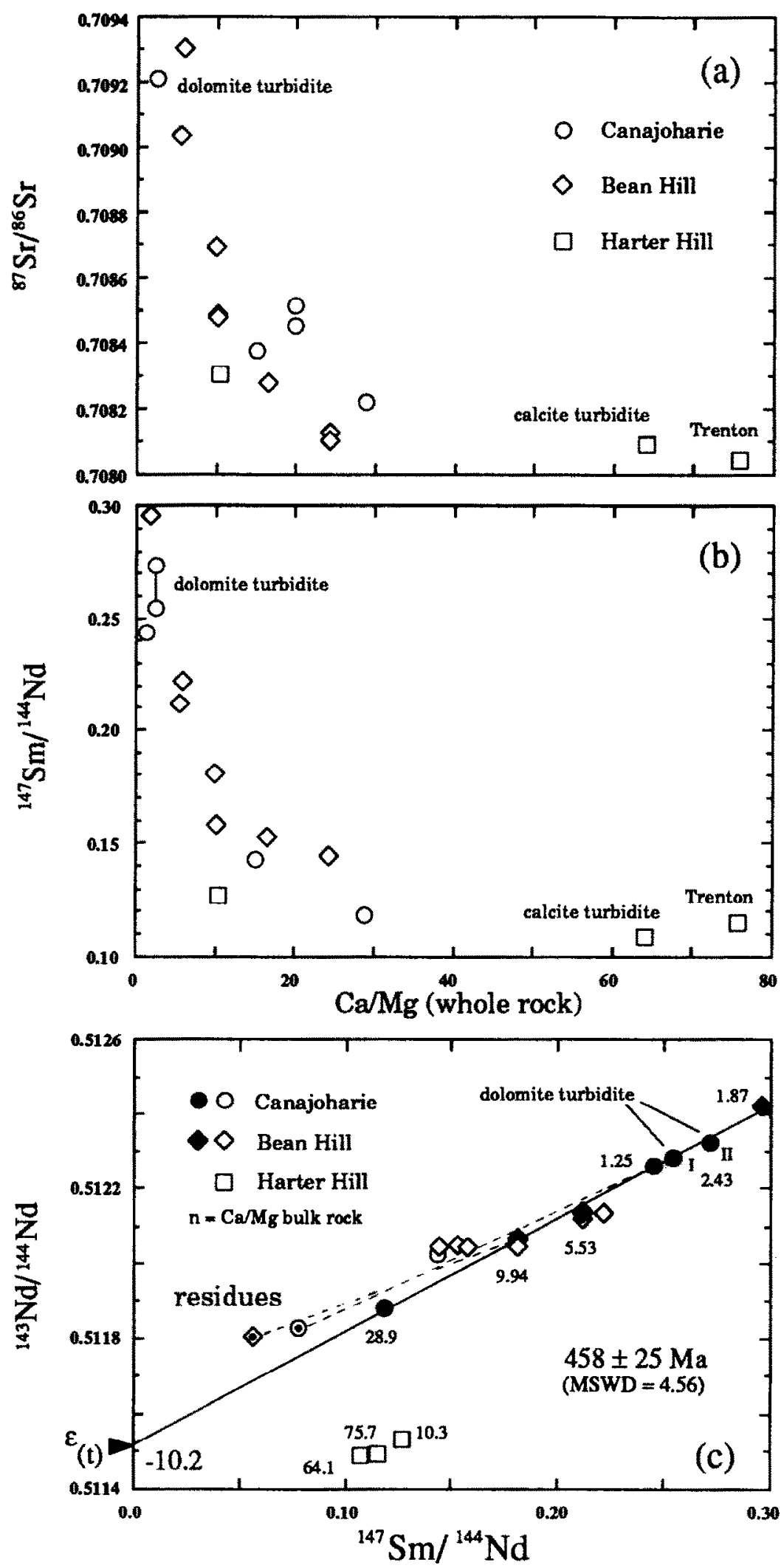

FiG. 9. Strontium isotopic and Sm-Nd results for the Middle Ordovician (454 Ma) shale samples (Utica Formation, New York, USA ). (a) ${ }^{87} \mathrm{Sr} /{ }^{86} \mathrm{Sr}$ and (b) ${ }^{147} \mathrm{Sm} /{ }^{144} \mathrm{Nd}$ of whole-rock leachates are plotted against the bulk rock Ca-Mg ratio. The calcitic samples have ${ }^{87} \mathrm{Sr} /{ }^{86} \mathrm{Sr}$ as low as 0.7081 (similar to Ordovician seawater) and ${ }^{147} \mathrm{Sm} /{ }^{144} \mathrm{Nd}$ as low as 0.118 . The dolomitic samples have elevated ${ }^{87} \mathrm{Sr} /{ }^{86} \mathrm{Sr}$ and ${ }^{147} \mathrm{Sm} /{ }^{144} \mathrm{Nd}$ as high as 0.296 . Samarium and neodymium in the leachates are fractionated as a function of carbonate cement composition. (c) The filled symbols correspond to leachate data derived from separately spiked samples, and define a depositional isochron age of $458 \pm 25 \mathrm{Ma}$. Two bulk rock residues have more radiogenic $\mathrm{Nd}$, indicating the presence of young volcanogenic detritus. 


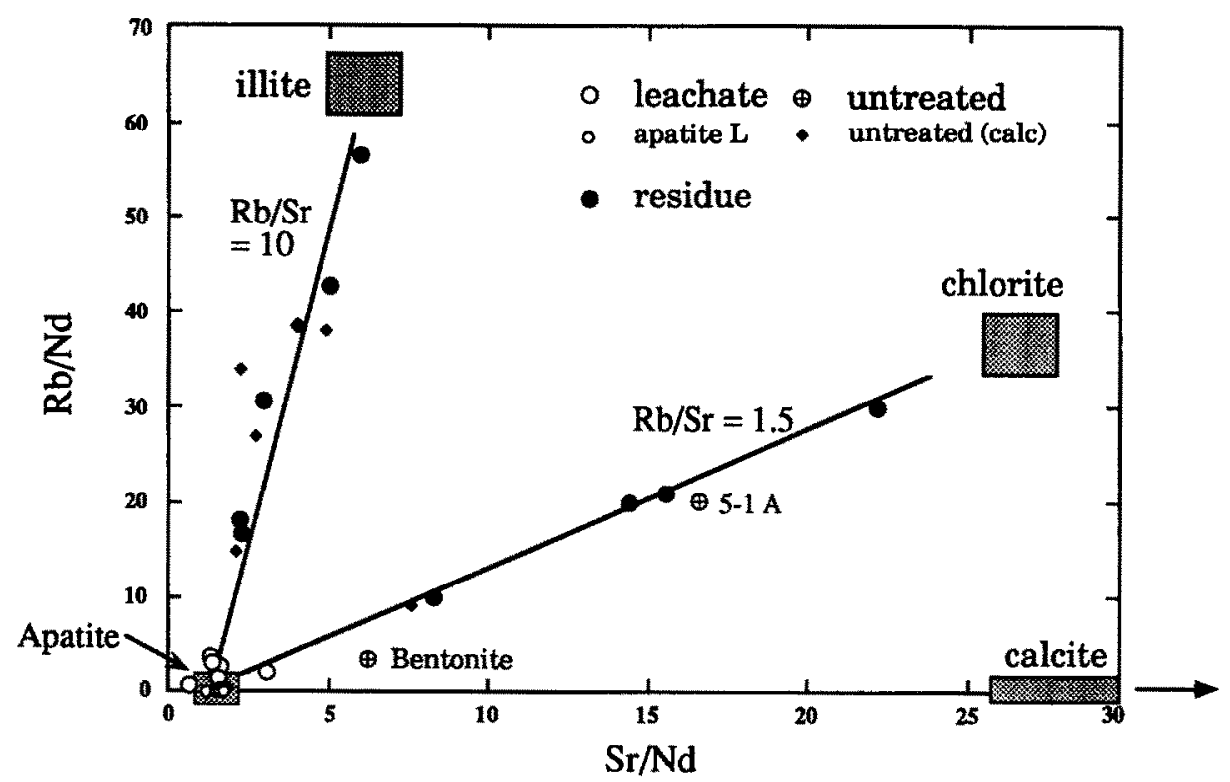

Fig. 10. Sr/Nd vs. Rb/Nd plot for samples from Wales. Leachate and residue data plotted are for illite-rich samples W2a, W16.I, and W16.2, and for chlorite-rich samples W5.1 and W25. Both trends intersect at leachate values of Rb/ $\mathrm{Nd}=0$ and $\mathrm{Sr} / \mathrm{Nd}=1.5$. Macroscopic apatite nodules (small open circles) have very similar $\mathrm{Sr} / \mathrm{Nd}$ between 1.25 and 1.70 , affirming the close affinity between leachate and apatite chemistry.

This conclusion is further endorsed by considering the trace element ratios $\mathrm{Sr} / \mathrm{Nd}$ and $\mathrm{Rb} / \mathrm{Nd}$ (Fig. 10). Combined $\mathrm{Rb}$ $\mathrm{Sr}$ and $\mathrm{Sm}-\mathrm{Nd}$ data were obtained for two groups of Welsh samples, a suite of chlorite-rich turbidites corresponding to the anchizone (Table 4), and a suite of uncleaved, illite-rich mudstones corresponding to the diagenetic zone (Table 2). The two rock suites define two distinct trends related to the high $\mathrm{Rb}-\mathrm{Sr}$ ratio in the illite-rich rocks, as compared to the low $\mathrm{Rb}-\mathrm{Sr}$ ratio in the chlorite-rich rocks. When interpolated to zero Rb-Nd ratio, both trends intersect at the same low

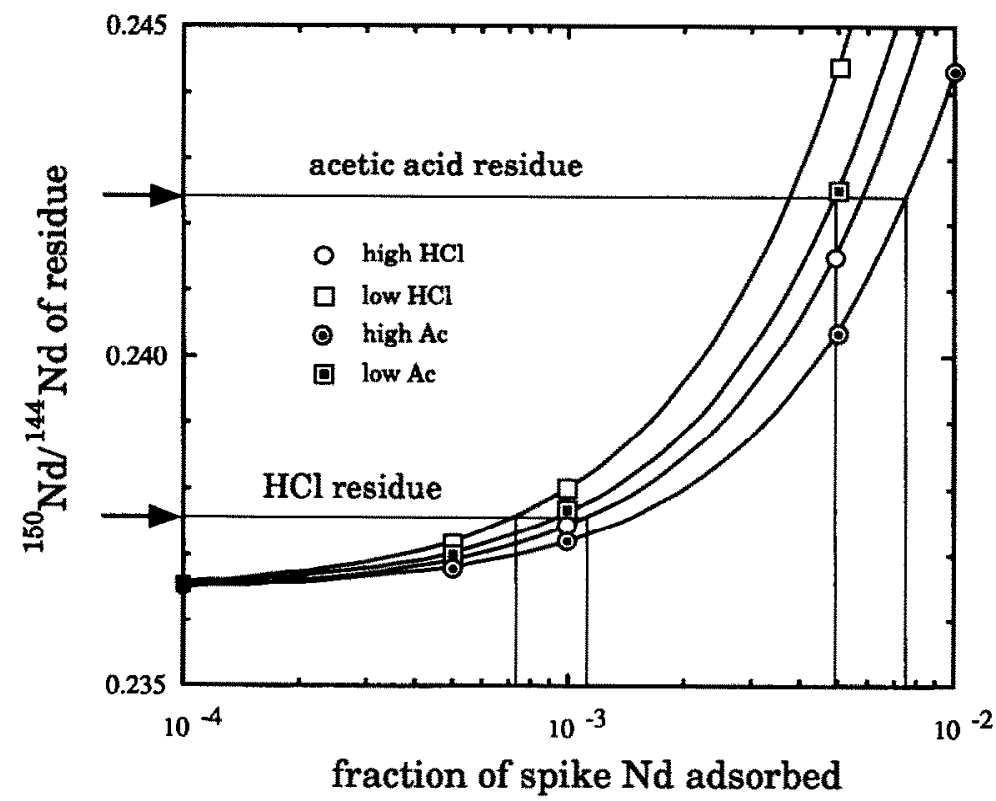

FiG. 11. Model results of an adsorption experiment where the $<0.2 \mu \mathrm{m}$ fraction of $\mathrm{W} 16.2$ was leached with spiked acid solutions. After discarding the leachate, the measured residue ${ }^{150} \mathrm{Nd} /{ }^{144} \mathrm{Nd}$ deviate only slightly from the natural isotopic ratio of 0.23647 , indicating minor (0.07-0.75\%) readsorption of dissolved Nd on grain surfaces. "High" and "Low" refer to maximum and minimum Nd concentrations of W16.2 (Table 2), respectively. 
Sr-Nd ratio of about 1.5. The same value is derived directly from macroscopic apatite concretions (Table 4). The two trends are basically mixing lines along constant $\mathrm{Rb}-\mathrm{Sr}$ ratios, modified only by the relative percentage of $\mathrm{Sr}$ and $\mathrm{Nd}$ that are sequestered in the apatite endmember at zero $\mathrm{Rb} / \mathrm{Nd}$.

We propose that the Sm-Nd system in clay-size separates of pelites can be approximated to a two-component system that involves diagenetic phyllosilicates and apatite. First, the observed Sm-Nd ages clearly demonstrate this to be an ancient feature that corresponds to the time of deposition or early burial. Second, the complementary REE patterns of leachate and residue suggest that the involved phases have dependent trace element characteristics. When dating diagenesis in this way, it is important to show that arguments constraining the common origin of apatite and phyllosilicates in terms of time and fractionation process can be made independently of one another.

Procedural artifacts that may produce the observed REE distribution must be addressed. Such leaching artifacts may be related to preferential adsorption of lanthanides on grain surfaces (e.g., SHOLKOVITZ, 1989), or to differential retention of REEs due to incomplete dissolution. We have investigated the possibility that MREEs might be preferentially released during the leaching process, while LREEs and HREEs are retained in the residue due to adsorption on grain surfaces. In a dissolution-resorption experiment the clay separate of W16.2 was exposed to both a spiked $1 \mathrm{~N} \mathrm{HCl}$ solution and a spiked acetic acid solution, thus mimicking the leaching process. The solution was then discarded, and the residue was rinsed repeatedly and subsequently dissolved following standard procedure. The isotopic compositions of $\mathrm{Ce}, \mathrm{Nd}$, and $\mathrm{Eu}$ were measured to determine if there had been any resorption of REEs from the spiked acids. No significant deviation from the natural isotopic ratios of $\mathrm{Ce}, \mathrm{Nd}$, and $\mathrm{Eu}$ in the residue was detected (Table 4). In Fig. 11 the expected ${ }^{150} \mathrm{Nd} /{ }^{144} \mathrm{Nd}$ of the residue is modeled as a function of the fraction of spike Nd adsorbed from the acid solution. The natural ratio is 0.23642 , and the measured ratios are 0.23762 and 0.24206 for the $\mathrm{HCl}$ and acetic acid leach, respectively. For the given sample and spike weights these ratios correspond to an adsorption of $0.07-0.1 \%$ of the dissolved $\mathrm{Nd}$ in $1 \mathrm{~N} \mathrm{HCl}$, and $0.5-0.7 \%$ of the dissolved $\mathrm{Nd}$ in acetic acid. Although the less acidic solution appears to be more prone to REE adsorption (see also SHOLKOVITZ, 1989), in both cases the observed effect is not nearly large enough to fractionate the REEs to the extent documented.

There may be the possibility that HREEs and LREEs are held in insoluble phases, and that the preferential release of MREEs into leachates merely reflects the retention of those insoluble phases in the residue. Monazite, florencite-group minerals, and zircon are all likely candidates. As monazite is attacked by and partially soluble in $\mathrm{HCl}$ and is the most LREE-enriched phase, one would expect that leaching with $\mathrm{HCl}$ would result in LREE enrichment in the leachate. However, the $\mathrm{La}-\mathrm{Yb}$ ratio of the $\mathrm{HCl}$ leachate of both $\mathrm{ZB1} 1 \quad(<0.1$ $\mu \mathrm{m})$ and W22.2 $(<0.2 \mu \mathrm{m})$ is only about two times the La$\mathrm{Yb}$ ratio of the corresponding acetic acid leachates, respectively. In addition, the overall shale-normalized REE pattern of the $\mathrm{HCl}$ leachates is still depleted in LREEs (Fig. 7d).
Therefore, we do not consider that retention of REEs in monazite or other residual phases figures prominently in the observed REE fractionation between the two leachates and the residue.

\section{Apatite diagenesis and burial metamorphism}

In studying the geochronology of fine-grained sediments, the occurrence of mixed-phase assemblages is certainly not an unexpected complication. A widely encountered problem is the presence of inherited source components in the sediment, although a number of workers have described ways to correct for such inheritance or, preferably, to avoid it altogether (LIEWIG et al., 1987, CLAUER et al., 1990; MOSSMAN, 1991; Pevear, 1992). The great majority of these data stem from detailed $\mathrm{Rb}-\mathrm{Sr}$ and $\mathrm{K}$-Ar work on mica and clay separates. The observed relation between grain size and $\mathrm{Sm}-\mathrm{Nd}$ age in the present study is a useful addition in this respect, demonstrating that source effects can be canceled out by combining careful separation of authigenic fractions with the advantage of a single sample dating scheme.

Just as uncertainties exist about the initial argon isotopic composition of a pore fluid that partly or fully equilibrated with radiogenic detritus, so the initial neodymium isotopic composition of a fluid may also have been variable as a function of short-term fluctuations of the source parameters. Unlike $\mathrm{K}$ and $\mathrm{Ar}$, however, $\mathrm{Sm}$ and $\mathrm{Nd}$ were fractionated at or shortly after deposition into authigenic phases that appear to be chemically separable in the laboratory, and that have managed to retain the daughter element through time. These two circumstances allow us to infer the initial neodymium isotopic composition and hence calculate an age, as is the case with any other dating scheme that contains a correction for the nonradiogenic daughter element component.

In the case of pelites of the diagenetic zone that have not developed a penetrative cleavage, $\mathrm{Sm}-\mathrm{Nd}$ ages agree within error with their stratigraphic ages. We consider these ages to be approximate equivalents of mineral-mineral ages involving authigenic apatite and mica. However, apatite and authigenic phyllosilicates very likely have not formed during the same diagenetic event, for it has been argued that the formation of authigenic apatite is an early diagenetic event which takes place close to the water-sediment interface (e.g., JAHNKE et al., 1983; GLENN and ARTHUR, 1988; VAN CAPPELLEN and BERNER, 1988). The formation of authigenic illite, on the other hand, takes place upon subsequent burial (e.g., KISCH, 1983).

The "isotopic event" of interest is the early diagenetic redistribution of REEs and the associated availability of phosphorus in the porewater. The uptake of REEs into originally REE-depleted biogenic apatite is governed by the coupled substitutions of $\mathrm{Si}^{4+} / \mathrm{P}^{5+}$ in the tetrahedral sites, and $\mathrm{REE}^{3+} /$ $\mathrm{Ca}^{2+}$ and $\mathrm{Na}^{+} / \mathrm{Ca}^{2+}$ in the two $\mathrm{Ca}$ sites. Although crystal structure refinements of REE-bearing apatite indicate that $\mathrm{Nd}^{3+}$ should most readily substitute in the Ca sites (HUGHES et al., 1991), $\mathrm{Gd}^{3+}$ is most enriched in diagenetic apatite (e.g., WRIGHT et al., 1987; GRANDJEAN and ALBAREDE, 1989; MULODOWSKI and ZALASKIEWICZ, 1991). The required supply of REEs is thought to be released from the bulk sediment 
by a variety of processes. These include the decomposition of organic matter, the reduction of hydrous $\mathrm{Mn}$ and Fe oxides, and the dissolution of fish debris, causing enhanced concentrations of REEs and dissolved phosphorus in porewaters of anoxic bottom sediments (ELDERFIELD et al., 1981; ELDERFIELD and SHOLKOVITZ, 1987; SHOLKOVITZ et al., 1989). From experimental growth rates (VAN CAPPELLEN and BERNER, 1991) the grain sizes of authigenic apatite have been predicted to be on the order of $0.1-10 \mu \mathrm{m}$, which is also the range of crystal sizes observed in our samples. The apparent preferential incorporation of LREEs and HREEs into authigenic illite and chlorite upon subsequent burial is probably a passive feature, inherited from the primary fractionation during apatite precipitation. Implicit in this suggestion is that the sediment has remained closed to further REE transport into or out of the system. As long as phyllosilicate diagenesis is completed within 10 to $15 \mathrm{~m} . \mathrm{y}$. (equivalent to a $10 \mathrm{ppm}$ increase in ${ }^{143} \mathrm{Nd} /{ }^{144} \mathrm{Nd}$ using an average ${ }^{147} \mathrm{Sm} /{ }^{144} \mathrm{Nd}$ of 0.11 ) after phosphate diagenesis, the resulting $\mathrm{Sm}-\mathrm{Nd}$ ages will still reflect depositional ages within error. Considering the diachronous character of primary REE fractionation and subsequent passive REE uptake into illite and chlorite, the rate of basin subsidence becomes an important parameter. For instance, even in rapidly subsiding basins such as the Texas Gulf Coast, illitization may take place $4 \mathrm{~m}$.y. to 20 m.y. after deposition (MORTON, 1985; OHR et al., 1991).

The initial neodymium isotopic composition of the apatitedominated component in the Welsh rocks is quite narrow, having $\epsilon_{(\mathrm{Nd}) t}$ values between -6 and -7 . Considering the wide range in initial $\epsilon_{(\mathrm{Nd})}$ values that has been documented in Lower Paleozoic sediments from Wales (THOROGOOD, 1990 ), this reflects a well-defined provenance. The isotopic homogeneity may be either related to the circumstantial absence of juvenile volcanic material, or to the lack of REE mobilization out of mafic volcanic phases during early diagenesis. This scenario would explain why the residues of the diagenetic zone and the anchizone always plot on or above the 460-Ma reference line through the leachate data, that is, always toward a more radiogenic Nd component (Fig. 3a).

We interpret the transitional ages of higher grade samples that have developed a tectonic fabric to be the result of a mixture of original diagenetic illite and newly formed tectonic mica. LI et al. (1993) described the texture and composition of chlorite and white mica in Llandoverian slates from central Wales, a sequence mineralogically and stratigraphically very similar to the present samples corresponding to the anchizone and the epizone. They found bedding- and cleavage-parallel phyllosilicates in the matrix, both extremely fine grained ( 100 Â to $2 \mu \mathrm{m}$ ), but having different structural and textural characteristics and also different compositions. LI et al. (1993) concluded that they formed during two distinct episodes, an earlier episode corresponding to initial burial without great disturbance of the depositional fabric, and a later episode corresponding to regional metamorphism and the development of a tectonic fabric.

As the separation of different generations of phyllosilicates depends entirely on differences in size, it must be expected that fine-grained separates of higher grade pelites will contain the same mixed assemblage as described by LI et al. (1993).
Our results are therefore entirely consistent with their description of mixed mica parageneses in the anchizone and epizone. In an ironic reversal of fortune from studies where detrital material is the contaminant of authigenic fractions, the dating of regional metamorphism in these rocks is hindered by what may be called "authigenic inheritance." $\mathrm{Al}$ though we cannot entirely rule out the possibility that detrital material contributed to the measured ages of these higher grade samples (in essence creating a three-component mixed age), it can be argued that the observed depositional ages in the undeformed, diagenetic samples indicate the near-absence of detrital contamination in these size fractions. Unfortunately, the lack or the small degree of Sm-Nd fractionation in the higher grade rocks introduces large errors in the L-R ages. These uncertainties render a rigorous graphical approach to estimating the time of regional metamorphism difficult, although a mixing line connecting high and low values of $\Delta 2 \theta$ could be optimistically drawn to indicate approximately the time of Acadian deformation of about $390 \mathrm{Ma}$ (Fig. 6).

\section{Prograde modifications}

Direct SEM observations and the low Sm-Nd ratios of leachates from epizonal rocks suggest that apatite might be replaced at higher grades by $\mathrm{REE}$-enriched phases that are also partially soluble. Monazite $\left(\mathrm{CePO}_{4}\right)$, sphene $\left.(\mathrm{CaTiSiO})_{5}\right)$, and florencite $\left(\mathrm{CeAl}_{3}\left(\mathrm{PO}_{4}\right)_{2}(\mathrm{OH})_{6}\right)$ are increasingly common in the epizone (Fig. $2 \mathrm{~d}, \mathrm{f}$ ), and are possible products of prograde reactions that also involve apatite $\left(\mathrm{Ca}_{5}\left(\mathrm{PO}_{4}\right)_{3}(\mathrm{OH}, \mathrm{F})\right.$ ), rutile $\left(\mathrm{TiO}_{2}\right)$, muscovite $\left(\mathrm{KAl}_{3} \mathrm{Si}_{3} \mathrm{O}_{10}(\mathrm{OH})_{2}\right)$, and quartz, such as

$$
\begin{aligned}
& \text { Apatite }+5 \text { rutile }+3 \text { muscovite }+3 \text { monazite }+2 \mathrm{H}_{2} \mathrm{O} \\
& +3 \mathrm{H}^{+}=5 \text { sphene }+3 \text { florencite }+4 \text { quartz }+3 \mathrm{~K}^{+}
\end{aligned}
$$

A monazite-producing reaction involving apatite is envisioned by AKERS et al. (1992), albeit at somewhat higher temperatures. Monazite and sphene are common accessory phases in medium- to high-grade pelitic rocks, but are not considered stable under conditions of diagenesis and very low-grade metamorphism by some (HARRISON et al., 1990). However, authigenic sphene has been described in Gulf Coast mudrocks (MILLIKEN and MACK, 1989; OHR et al., 1991). Besides apatite, LREE oxides and hydrous REE phosphates might also be carriers of the REEs at low temperature, e.g.,

3 monazite + apatite +7 calcite +3 quartz $+3 \mathrm{H}_{2} \mathrm{O}$

$$
=3 \mathrm{CeCa}_{4}\left(\mathrm{PO}_{4}\right)_{2} \mathrm{SiO}_{4}(\mathrm{OH})+7 \mathrm{CO}_{2}
$$

The original content of organic material is another important factor in controlling the abundance of early diagenetic apatite, as much of the dissolved phosphorus in porewaters is derived from the decomposition of organic matter. In this study, the highest Sm-Nd ratios were observed in the leachates of black graptolitic shales with high organic carbon content. The epizonal slates that yield low Sm-Nd ratios in their leachates may never have developed an abundant population of diagenetic apatite due to a low content of original organic matter. In that case, the potential for using the diagenetic 
$\mathrm{Sm}-\mathrm{Nd}$ fractionation in pelitic rocks to constrain stratigraphic ages would be mainly dependent on the availability of organic material during burial, while subsequent prograde modifications of phosphate phases may be of secondary importance.

\section{Diagenesis and neodymium model ages}

Diagenetic modifications of the Sm-Nd system in argillaceous sediments involve mobility and fractionation of the REEs under near-surface conditions. This is potentially of significance to the interpretation of Nd model ages in sediments. This approach to modeling the growth and evolution of the continental crust routinely assumes near-immobility of the REEs. We have shown that fractionation and diagenetic uptake of the REEs into apatite, and growth of authigenic phyllosilicates during burial are concurrent features and result in lower Sm-Nd ratios in diagenetic illite and chlorite. The low-temperature redistribution of the REEs may be called "nonconservative," as it involves phases of different solubility and grain size which also undergo different prograde reaction paths. Hence, for rocks of variable grain size and metamorphic grade, variations of Nd model ages are likely to include a diagenetic effect and are not solely related to source parameters. Unfortunately, this data set provides insufficient information on the relation of Sm-Nd ratios between wholerock and fine fractions to evaluate the magnitude of this effect. Further study focusing on sediments with constant provenance is needed to address this important question.

\section{CONCLUSIONS}

The main conclusions of this study may be summarized as follows.

1) Redistribution of REEs in argillaceous rocks during early diagenesis and burial causes pronounced Sm-Nd fractionation in sediments between acid-soluble and residual fractions. The two fractions are dominated by diagenetic apatite and fine-grained illite and chlorite, respectively, and can be separated by a simple leaching technique.

2) The extent of the presently observed Sm-Nd fractionation is a function of grain size, metamorphic grade, and probably original content of organic matter. Prograde reactions involving REE-rich accessory phases such as apatite, monazite, florencite, and sphene modify the REE distribution imparted from diagenesis and burial.

3) Leachate-residue Sm-Nd ages correspond within error to stratigraphic ages in uncleaved rocks of the diagenetic zone, and to transitional ages toward the timing of metamorphism in rocks of the anchizone and epizone. For all rocks studied, the $\mathrm{Sm-Nd}$ system has remained closed subsequent to diagenesis or metamorphism. It has not been isotopically reset during later hydrothermal alteration events, such as the Alleghenian age remagnetization of North American Paleozoic limestones.

4) The effects of initial neodymium isotopic heterogeneity are cancelled by the single-sample approach employed in this study. The total range of initial ${ }^{143} \mathrm{Nd} /{ }^{144} \mathrm{Nd}$ in leachates of argillaceous rocks from Wales is narrow $\left(\epsilon_{(\mathrm{Nd}) t}\right.$ $=-6$ to -7 ); coupled with the observed range in leachate
Sm-Nd ratios, it may be possible to exclusively use the soluble fractions to obtain ages of diagenesis.

Acknowledgments-We thank R. Merriman and B. Roberts for their guidance and expertise during field work in Wales, and J. W. Delano for providing the Ordovician samples from New York state. R. Keller and Ted Huston provided technical assistance in the laboratory. We are also grateful to C. DeWolf, G. Davies, E. Essene, K. Mezger, and L. Walter for discussion and criticism. The original version of the manuscript was much improved by the constructive reviews of S. Hemming, L. Mack, and P. Vrolijk. This research was supported by NSF grants EAR-9104877 to ANH, and EAR-9005516 to DRP. MO was partially supported through a dissertation stipend of the Studienstiftung des Deutschen Volkes (The German National Scholarship Foundation ).

Editorial handling: S. M. McLennan

\section{REFERENCES}

Akers W. T., Grove M., Harrison T. M., and Ryerson F. J. (1992) The stability of rhabdophane and its implications for monazite thermochronology. V. M. Goldschmidt Conf. 1992, Prog. Abstr., A-1 (abstr.).

AWWILLER D. N. and MACK I. E. (1991) Diagenetic modifications of Sm-Nd model ages in Tertiary sandstones and shales, Texas Gulf Coast. Geology 19, 311-314.

BEVINS R. E. and ROBINSON D. (1988) Low-grade metamorphism of the Welsh basin Lower Paleozoic succession: An example of diastathermal metamorphism. J. Geol. Soc. London 145, 363366.

Bevins R. E., Robinson D., Rowbotham G., and DUNKLEy P. N. (1981) Low-grade metamorphism in the Welsh Caledonides. $J$. Geol. Soc. London 138, 634-642.

Bevins R. E., Oliver G. J. H., and Thomas L. J. ( 1985) Low-grade metamorphism in the paratectonic Caledonides of the British Isles. In The Tectonic Evolution of the Caledonian-Appalacian Orogeny (ed. R. A. GAYER); Earth Evolution Sci. Mem. 1, 57-79.

Bros R., Stille P., Gauthier-Lafaye F., Weber F., and Clauer N. (1992) Sm-Nd isotopic data of Proterozoic clay material: An example from the Francevillian sedimentary series, Gabon. Earth Planet. Sci. Lett. 113, 207-218.

BURKE W. H., DENISON R. E., HETHERINGTON E. A., KoEPENICK R. B., NELSON H. F., and OTTO J. B. (1982) Variation of seawater ${ }^{87} \mathrm{Sr} /{ }^{86} \mathrm{Sr}$ throughout Phanerozoic time. Geology 10, 516-519.

Chaudhuri S. and BRookins D. G. (1979) The Rb-Sr systematics in acid leached clay minerals. Chem. Geol. 24, 231-242.

Clauer N., O'NeIL J. R., BONNOT-Courtois C., and HoltzaPFFel T. (1990) Morphological, chemical, and isotopic evidence for an early diagenetic evolution of detrital smectite in marine smectite. Clays Clay Minerals 38, 33-46.

Clauer N., Chaudhuri S., Kralik M., and Bonnot-Courtois C. (1993) Effects of experimental leaching on $\mathrm{Rb}-\mathrm{Sr}$ and $\mathrm{K}-\mathrm{Ar}$ isotopic systems and REE contents of diagenetic illite. Chem. Geol. (in press).

DeWolf C. P. and Halliday A. N. (1991) U-Pb dating of a remagnetized Paleozoic limestone. Geophys. Res. Lett. 18, 14451448.

ELDERFIELD H. and E. R. SHOLKOVITZ E. R. (1987) Rare earth elements in the porewaters of reducing nearshore sediments. Earth Planet. Sci. Lett. 82, 280-288.

ELDERFIELD H., HaWkesWoRTH C. J., and GREAVES M. J. ( 1981 ) Rare earth element geochemistry of oceanic ferromanganese nodules and associated sediments. Geochim. Cosmochim. Acta 45, 513-528.

EvanS J. A. ( 1991 ) Resetting of Rb-Sr whole-rock ages during Acadian low-grade metamorphism in North Wales. J. Geol. Soc. London 148, 703-710.

FORTEY R. A. and COCKS L. R. M. (1988) Arenig to Llandovery faunal distributions in the Caledonides. In The Caledonian and 
Appalachian Orogen (ed. A. L. HARRIS and D. J. FetTes); Geol. Soc. Spec. Publ. 38, 233-246.

GLENN C. R. and ARTHUR M. A. (1988) Petrology and major element geochemistry of Peru margin phosphorites and associated diagenetic minerals: Authigenesis in modern organic-rich sediments. Mar. Geol. 80, 231-267.

GRANDJEAN P. and ALBAREDDE F. (1989) Ion probe measurement of rare earth elements in biogenic phosphates. Geochim. Cosmochim. Acta 53, 3179-3183.

GRANDJEAN P., CAPETTA H., MICHARD A., and ALBAREDE F. (1987) The assessment of REE patterns and ${ }^{143} \mathrm{Nd} /{ }^{144} \mathrm{Nd}$ ratios in fish remains. Earth Planet. Sci. Lett. 84, 181-196.

Gromet L. P., DYMET R. F., HASkin L. A., and Korotev R. L, (1984) The North American Shale composite: Its compilation, major and trace element characteristics. Geochim. Cosmochim. Acta 48, 2469-2482.

Halliday A. N, Mahood G. A., Holden P., Metz J. M., DempsTER T. J., and DAVIDSON J. P. (1989) Evidence for long residence times of rhyolitic magma in the Long Valley magmatic system: The isotopic record in precaldera lavas of Glass Mountain. Earth Planet. Sci. Lett. 94, 274-290.

Halliday A. N., Ohr M., Mezger K., Chesley J. T., Nakai S., and C. P. DEWOLF C. P. (1991) Recent developments in dating ancient crustal fluid flow, Rev. Geophys. 29, 577-584.

Harland W. B., Cox A. V., Llewelly y. P. G., Pickton C. A. G., SMith A. G., and Walters R. A. (1982) A Geologic Time Scale. Cambridge Univ. Press.

Harland W. B., ARMSTRong R. L., CoX A. V., Craig L. E., SMITH A. G., and SMITH D. G. (1990) A Geologic Time Scale, 1989. Cambridge Univ. Press.

Harrison T. M., Kingsbury J, and Miller C. F. (1990) Prograde thermochronology: U-Pb dating of monazite growth. $V$. M. Goldschmidt Conf. 1990, Prog. Abstr., A-52 (abstr.).

HEARN P. P. and SUTTER J. F. (1985) Authigenic potassium feldspar in Cambrian carbonates: Evidence of Alleghenian brine migration. Science 228, 1529-1531.

Hughes J. M., Cameron M., and Mariano A. N. (1991) Rareearth element ordering and structural variations in natural rareearth bearing apatites. Amer. Mineral. 76, 1165-1173.

JAHNKe R, A., EMERSON S. R., ROE K. K., and BuRNetT W. C. (1983) The present day formation of apatite in Mexican continental margin sediments. Geochim. Cosmochim. Acta 47, 259-266.

KENT D. V. (1985) Thermoviscous remagnetization in some Appalachian limestones. Geophys. Res. Lett. 12, 805-808.

KETO L. S. and JACOBSON S. B. (1987) Nd and Sr isotopic variations in seawater. Earth Planet. Sci. Lett. 84, 27-41.

KISCH H. J. (1983) Mineralogy and petrology of burial diagenesis (burial metamorphism) and incipient metamorphism in clastic rocks. In Diagenesis in Sediments and Sedimentary Rocks (ed. G. I.ARSEN and G. V. CHILINGAR ), 289-493. Elsevier.

KokelaAR B. P., Howells M. F., BEvins R. E., ROACH R. A., and DUNKLEY P. N. (1984) The Ordovician marginal basin of Wales. In Marginal Basin Geology (ed. B. P. KoKeLAAR and M. F. HowELLS); Geol. Soc. Spec. Publ. 16, 245-269.

KRALIK M. (1984) Effects of cation exchange treatment and acid leaching on the Rb-Sr system of illite from Fithian, Illinois. Geochim. Cosmochim. Acta 48, 527-533.

LEFEBVRE J. J. and GASPARINI C. (1980) Florencite, an occurrence in the Zairian copperbelt. Canadian Mineral. 18, 301-311.

Li G., Peacor D. R., Merriman R. J., Roberts B., and VAN DER PLUUM B. A. (1993) TEM and AEM constraints on the origin and significance of chlorite-mica stacks in slates: An example from central Wales, U.K. J. Struct. Geol. (in review).

LIEWIG N., ClaUeR N., and SOMmer F. (1987) Rb-Sr and K-Ar dating of clay diagenesis in Jurassic sandstone oil reservoir, North Sea. AAPG Bull. 71, 1467-1474.

Masuda A., NAKamURA N., and TANAKa T. (1973) Fine structures of mutually normalized rare-earth patterns of chondrites. Geochim. Cosmochim. Acta 37, 239-251.

MCCABE C. and ELMORE R. D. (1989) The occurrence and origin of Late Paleozoic remagnetization in the sedimentary rocks of North America. Rev. Geophys. 27, 471-494.
MCCabe C., VAN DeR VoO R., and Ballard M. M. (1984) Late Paleozoic remagnetization of the Trenton Limestone. Geophys. Res. Lett. 11, 979-982.

MCKERROW W. S. (1988) Wenlock to Givetian deformation in the British Isles and the Canadian Appalachians. In The Caledonian and Appalachian Orogen (ed. A. L. HARRIS and D. J. FETTES); Geol. Soc. Spec. Publ. 38, 437-448.

MCKERROW W. S., LAMBERT R. S., and CoCKS R. L. M. (1985) The Ordovician, Silurian and Devonian Periods. In Geochronology and the Geological Record (ed. N. J. SNELLING); Geol. Soc. Mem. 10, 73-80.

MC LENNAN S. M. (1991) Rare earth elements in sedimentary rocks: influence of provenance and sedimentary processes. In Geochemistry and Mineralogy of Rare Earth Elements (ed. B. R. LIPIN and G. A. MCKAY); Rev. Mineral. 21, 169-200.

MERRIMAN R. J. and ROBERTS B. (1985) A survey of white mica crystallinity and polytypes in pelitic rocks of Snowdonia and Llyn, North Wales. Mineral. Mag. 49, 305-319.

MILLIKEN K. L. and MACK L. E. (1989) Comparison of detrital and authigenic heavy minerals in the modern Rio Grande and the Oligocene Frio Formation, south Texas. GSA Ahstr. Prog. 21, no. 6, A17 (abstr.).

MiLODOWSKI A. E. and ZALASKIEWICZ J. A. (1991) Redistribution of rare earth elements during diagenesis of turbidite / hemipelagite mudrock sequences of Llandovery age from Central Wales. In Developments in Sedimentary Provenance Studies (ed. A. C. MORTON et al.); Geol. Soc. Spec. Publ. 57, 101-125.

Mitchell C. E., Goldman D., Bergstrom S. M., Delano J. W., and SAMSON S. D. (1992) Chronostratigraphy of the Trenton Group and Utica Shale, Pt. I: Preliminary revision of lithofacies and age relationships. GSA Prog. Abstr. 23, A196 (abstr.).

MORTON J. P. (1985) Rb-Sr evidence for punctuated illite/smectite diagenesis in the Ogligocene Frio Formation, Texas Gulf Coast. Geol. Soc. Amer. Bull. 96, 114-122.

MossmanN J. R. (1991) K-Ar dating of authigenic illite-smectite clay material: Application to complex mixtures of mixed-layer assemblages. Clay Minerals 26, 189-198.

Ohr M., Halliday A. N., and Peacor D. R. (1991) Sr and Nd isotopic evidence for punctuated clay diagenesis, Texas Gulf Coast. Earth Planet. Sci. Lett. 105, 110-126.

OLIVER G. J. H. ( 1988 ) Arenig to Wenlock regional metamorphism in the Paratectonic Caledonides of the British Isles: a review. In The Caledonian and Appalachian Orogen (ed. A. L. HARRIS and D. J. FeTtes); Geol. Soc. Spec. Publ. 38, 347-364.

OLIVER W. A. (1956) Stratigraphy of the Onondaga Limestone in eastern New York. GSA Bull. 67, 1441-1474.

PEVEAR D. R. (1992) Diagenetic and detrital endmember K/Ar ages from shales: methods and applications. $V . M$. Goldschmidt Conf. 1992, Prog. Abstr., A-83 (abstr.).

RICK ARD L. V. ( 1975 ) Correlation of Silurian and Devonian rocks in New York State. $N$. Y. State Mus. Sci. Serv. Map Chart Series No. 24.

ROBERTS B. (1979) The Geology to Snowdonia and Llyn: An Outline and Field Guide. Adam Hulger.

ROBERTS B. (1981) Low-grade and very low-grade regional metabasic rocks of Llyn and Snowdonia, Gwynedd, North Wales. Geol. Mag. 118, 189-200.

ROBERTS B. and MERRIMAN R. J. (1985) The distinction between Caledonian burial and regional metamorphism in pelites from North Wales: An analysis of isocryst patterns. J. Geol. Soc. London $142,615-624$.

Roden M. K., PARrish R. R., and Miller D. S. (1990) The absolute age of the Eifelian Tioga ash bed, Pennsylvania. J. Geol. 98, 282285.

ROWLEY D. A. and KIDD W. S. F. ( 1981 ) Stratigraphic relationship and detrital composition of the medial Ordovician flysch of western New England; implications for the tectonic evolution of the Taconic orogeny. J. Geol. 89, 199-218.

SAMSON S. D., PATChett P. J., RoDdick J. C., and PARRISH R. R. (1989) Origin and tectonic setting of Ordovician bentonites in North America: isotopic and age constraints. GSA Bull. 101, 11751181. 
SHolkovitz E. R. (1989) Artifacts associated with the chemical leaching of sediments for rare earth elements. Chem. Geol. 77, 4751.

SHolkovitz E. R., PIEPGRAS D. J., and Jacorson S. B. (1989) The pore water chemistry of rare earth elements in Buzzards Bay sediment. Geochim. Cosmochim. Acta 53, 2847-2856.

Stille P. and Clauer N. (1986) Sm-Nd isochron-age and provenance of the argillites of the Gunflint Iron Formation in Ontario, Canada. Geochim. Cosmochim. Acta 50, 1141-1146.

STILLMAN C. J. (1988) Ordovician to Silurian volcanism in the Appalachian-Caledonian orogen. In The Caledonian and Appalachian Orogen (ed. A. L. HARRIS and D. J. FETTES); Geol. Soc. Spec. Publ. 38, 231-248.

SUK D., PEACOR D. R, and VAN DER VOo R. (1990) Replacement of pyrite framboids by magnetite in limestone and implications for palcomagnetism. Nature 345, 611-613.

TAYLOR S. R. and MCLENNAN S. M. (1985) The Continental Crust: Its Composition and Evolution. Blackwell.

THOROGOOD E. J. (1990) Provenance of the Pre-Devonian sediments of England and Wales. J. Geol. Soc. London 147, 591-594.
TUCKer R. D., KROGH T. E., ROSS R. J., and WILliams S. H. (1990) Time-scale calibration by high-precision U-Pb dating of interstratified volcanic ashes in the Ordovician and Lower Silurian stratotypes of Britain. Earth Planet. Sci. Lett. 100, 51-58.

VAN CAPPELLEN P. and BERNER R. L. (1988) A mathematical model for the early diagenesis of phosporus and fluorine in marine sediments: Apatite precipitation. Amer. J. Sci. 288, 289-333.

VAN CAPPELLEN P. and BERNER R. L. (1991) Fluorapatite growth from modified seawater solutions. Geochim. Cosmochim. Acta 55 , 1219-1234.

WADGE A. J., HARDING R. R., and DARBYSHIRE D. P. F. (1978) The rubidium-strontium age and field relationships of the Threlkeld Microgranite. Proc. Yorkshire Geol. Soc. 40, 211-222.

Woodcock N. H., Awan M. A., Johnson T. E., Mackie A. H., and SMITH R. D. A. (1988) Acadian tectunics of Wales during Avalonia/Laurentia convergence. Tectonics 7, 483-495.

Wright J., SCHRader H., and Holser W. T. (1987) Paleoredox variations in ancient oceans recorded by rare earth elements in fossil apatite. Geochim. Cosmochim. Acta 51, 631-644. 